NUREG/CR-5767

ORNL/Sub/90-SH640/1

RF

NUREG/CR- -5767

TI92 003575

\title{
The Behavior of Shallow Flaws in Reactor Pressure Vessels
}

Status Report

Manuscript Completed: September 1991

Date Published: November 1991

Prepared by

S. T. Rolfe

University of Kansas

Lawrence, KS 66045-2235

Under Contract to:

Oak Ridge National Laboratory

Operated by Martin Marietta Energy Systems, Inc.

Oak Ridge National Laboratory

Oak Ridge, TN 37831-6285

\section{Prepared for}

\section{Division of Engineering}

Office of Nuclear Regulatory Research

U.S. Nuclear Regulatory Commission

Washington, DC 20555

NRC FIN B0119

Under Contract No. DE-AC ${ }^{5} 5-840 R 21400$

\section{DISCLAIMER}

This report was prepared as an account of work sponsored by an agency of the United States employces, makes any the United States Government nor any agency thereof, nor any of their bility for the accuracy, completentess or implied, or assumes any legal liability or responsiprocess disclosed, or represents that its use wulness of any information, apparatus, product, or ence herein to any specific commer its use would not infringe privately owned rights. Refermanufacturer, or otherwise does not necessarily constitute or mendation, or favoring by the United States Gonstitute or imply its endorsement, recomand opinions of authors expressed herein United States Government or any agency thereof. 


\begin{abstract}
Both analytical and experimental research studies have shown that the effect of crack length, a, on the elastic-plastic toughness of structural steels is significant. The objective of this report is to recommend those research investigations that are necessary to understand the phenomenon of shallow behavior as it affects fracture toughness so that the results can be used properly in the structural margin assessment of reactor pressure vessels (RPVs) with flaws.

Preliminary test results of A 533 B steel show an elevated crack-tip-opening displacement (CTOD) toughness similar to that observed for structural steels tested at the University of Kansas. Thus, the inherent resistance to fracture initiation of A 533 B steel with shallow flaws appears to be higher than that used in the current American Society of Mechanical Engineers (ASME) design curves based on testing fracture mechanics specimeris with deep flaws. If this higher toughness of laboratory specimens with shallow flaws can be transferred to a higher resistance to failure in RPV design or analysis, then the actual margin of safety in nuclear vessels with shallow flaws would be greater than is currently assumed on the basis of deep-flaw test results. This elevation in toughness and greater resistance to fracture would be a very desirable situation, particularly for the pressurized-thermal shock (PTS) analysis in which shallow flaws are assumed to exist.

Before any advantage can be taken of this possible increase in initiation toughness, numerous factors must be analyzed to ensure the transferability of the data. This report reviews those factors and makes recommendations of studies that are needed to assess the transferability of shallow-flaw toughness test results to the structural margin assessment of RPV with shallow flaws.
\end{abstract}




\section{CONTENTS}

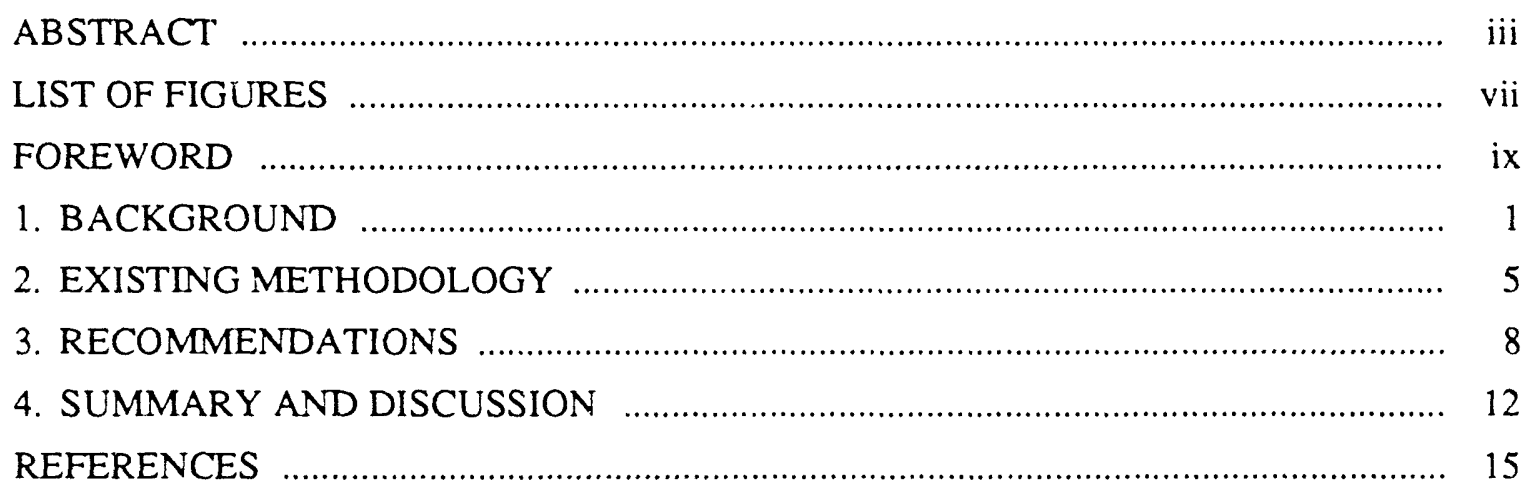




\section{LIST OF FIGURES}

Figure

1 Effect of a/W ratio on fracture toughness of A 36 and A 517 steels tested at the University of Kansas ......................................................................... 2

2 Effect of crack depth on fracture toughness of A 533 B steel ......................... 3

3 Effect of specimen thickness on fracture toughness of A 533 B steel ................ 4

4 Lower-bound $\mathrm{K}_{\mathrm{Ia}}$ and $\mathrm{K}_{\mathrm{Ic}}$ test data for SA 533 grade B class 1, SA 508 class 2, and SA 508 class 3 steels-ASME Sect. XI ....................................... 5

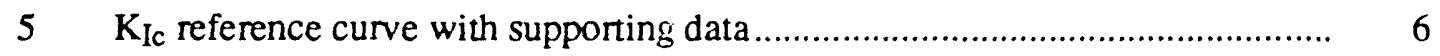

6 Comparison of $\beta_{\mathrm{Ic}}$ adjusted small-specimen static initiation toughness values with thick-section test results for TSE-5 and -6 materials

7 Crack-opening stress distributions for 31.8 - by $31.8-\mathrm{mm}$ A 36 steel specimens

8 Comparison of A 36 test results with ASME Sect. XI reference curve as example of "shallow-flaw" reference curve 


\section{FOREWORD}

The work reported here was performed at Oak Ridge National Laboratory under the Heavy-Section Steel Technology (HSST) Program, W. E. Pennell, Program Manager. The program is sponsored by the Office of Nuclear Regulatory Research of the U.S. Nuclear Regulatory Commission (NRC). The technical monitor for the NRC is M. E. Mayfield.

This report is designated HSST Report 114. Prior and future reports in this series are listed below.

1. S. Yukawa, General Electric Company, Schenectady, N.Y., Evaluation of Periodic Proof Testing and Warm Prestressing Procedures jor Nuclear Reactor Vessels, HSSTPTR-1, July $1,1969$.

2. L. W. Loechel, Martin Marietta Corporation, Denver, Colo., The Effect of Testing Variables on the Transition Temperature in Steel, MCR-69-189, November 20, 1969.

3. P. N. Randall, TP.W Systems Group, Redondo Beach, Calif., Gross Strain Measure of Fracture Toughness of Steels, HSSTP-TR-3, November 1, 1969.

4. C. Visser, S. E. Gabrielse, and W. VanBuren, Westinghouse Electric Corporation, PWR Systems Division, Pittsburgh, Pa., A Two-Dimensional Elastic-Plastic Analysis of Fracture Test Specimens, WCAP-7368, October 1969.

5. T. R. Mager and F. O. Thomas, Westinghouse Electric Corporation, PWR Systems Division, Pittsburgh, Pa., Evaluation by Linear Elastic Fracture Mechanics of Radiation Damage to Pressure Vessel Steels, WCAP-7328 (Rev.), October 1969.

6. W. O. Shabbits, W. H. Pryle, and E. T. Wessel, Westinghouse Electric Corporation, PWR Systems Division, Pittsburgh, Pa., Heavy-Section Fracture Toughness Properties of A533 Grade B Class 1 Steel Plate and Submerged Arc Weldment, WCAP-7414, December 1969.

7. F. J. Loss, Naval Research Laboratory, Washington, D.C., Dynamic Tear Test Investigations of the Fracture Toughness of Thick-Section Steel, NRL-7056, May 14, 1970.

8. P. B. Crosley and E. J. Ripling, Materials Research Laboratory, Inc., Glenwood, Ill., Crack Arrest Fracture Toughness of A533 Grade B Class 1 Pressure Vessel Steel, HSSTP-TR-8, March 1970.

9. T. R. Mager, Westinghouse Electric Corporation, PWR Systems Division, Pittsburgh, Pa., Post-Irradiation Testing of 2 T Compact Tension Specimens, WCAP-7561, August 1970.

10. T. R. Mager, Westinghouse Electric Corporation, PWR Systems Division, Pittsburgh, Pa., Fracture Toughness Characterization Study of A533, Grade B, Class I Steel, WCAP-7578, October 1970.

11. T. R. Mager, Westinghouse Elcctric Corporation, PWR Systems Division, Pittsburgh, Pa., Notch Preparation in Compact Tension Specimens, WCAP-7579, November 1970. 
12. N. Levy and P. V. Marcal, Brown University, Providence, R.I., Three-Dimensional Elastic-Plastic Stress and Strain Analysis for Fracture Mechanics, Phase I: Simple Flawed Specimens, HSSTP-TR-12, December 1970.

13. W. O. Shabbits, Westinghouse Electric Corporation, PWR Systems Division, Pittsburgh, Pa., Dynamic Fracture Toughness Properties of Heavy Section A533 Grade B Class 1 Steel Plate, WCAP-7623, December 1970.

14. P. N. Randall, TRW Systems Group, Redondo Beach, Calif., Gross Strain Crack Tolerance of A 533-B Steel, HSSTP-TR-14, May 1, 1971.

15. H. T. Corten and R. H. Sailors, University of Illinois, Urbana, Ill, Relationship Between Material Fracture Toughness Using Fracture Mechanics and Transition Temperature Tests, T\&AM Report 346, August 1, 1971.

16. T. R. Mager and V. J. McLaughlin, Westinghouse Electric Corporation, PWR Systems Division, Pittsburgh, Pa., The Effect of an Environment of High Temperature Primary Grade Nuclear Reactor Water on the Fatigue Crack Growth Characteristics of A533 Grade B Class 1 Plate and Weldment Material, WCAP-7776, October 1971.

17. N. Levy and P. V. Marcal, Brown University, Providence, R.I., Three-Dimensional Elastic-Plastic Stress and Strain Analysis for Fracture Mechanics, Phase II: Improved Modelling, HSSTP-TR-17, November 1971.

18. S. C. Grigory, Southwest Research Institute, San Antonio, Tex., Tests of 6-in.-Thick Flawed Tensile Specimens, First Technical Summary Report, Longitudinal Specimens Numbers I through 7, HSSTP-TR-18, June 1972.

19. P. N. Randall, TRW Systems Group, Redondo Beach, Calif., Effects of Strain Gradients on the Gross Strain Crack Tolerance of A533-B Steel, HSSTP-TR-19, June 15, 1972.

20. S. C. Grigory, Southwest Research Institute, San Antonio, Tex., Tests of 6-Inch-Thick Flawed Tensile Specimens, Second Technical Summary Report, Transverse Specimens Numbers 8 through 10, Welded Specimens Numbers 11 through 13, HSSTP-TR-20, June 1972.

21. L. A. James and J. A. Williams, Hanford Engineering Development Laboratory, Richland, Wash., Heavy Section Steel Technology Program Technical Report No. 21, The Effect of Temperature and Neutron Irradiation Upon the Fatigue-Crack Propagation Behavior of ASTM A533 Grade B. Class 1 Steel, HEDL-TME 72-132, September 1972.

22. S. C. Grigory, Southwest Research Institute, San Antonio, Tex., Tests of 6-Inch-Thick Flawed Tensile Specimens, Third Technical Summary Report, Longitudinal Specimens Numbers 14 through 16. Unflawed Specimer: Number 17, HSSTP-TR-22, October 1972.

23. S. C. Grigory, Southwest Research Institute, San Antonio, Tex., Tests of 6-Inch-Thick Tensile Specimens, Fourth Technical Summary Report, Tests of 1-Inch-Thick Flawed Tensile Specimens for Size Effect Evaluation, HSSTP-TR-23, June 1973. 
24. S. P. Ying and S. C. Grigory, Southwest Research Institute, San Antonio, Tex., Tests of 6-Inch-Thick Tensile Specimens, Fifth Technical Summary Report, Acoustic Emission Monitoring of One-Inch and Six-Inch-Thick Tensile Specimens, HSSTP-TR-24, November 1972.

25. R. W. Derby, J. G. Merkle, G. C. Robinson, G. D. Whitman, and F. J. Witt, Oak Ridge Natl. Lab., Oak Ridge, Tenn., Test of 6-Inch-Thick Pressure Vessels. Series 1: Intermediate Test Ve, :els $V-1$ and V-2, ORNL-4895, February 1974.

26. W. J. Stelzman and R. G. Berggren, Oak Ridge Natl. Lab., Oak Ridge, Tenn., Radiation Strengthening and Embrittlement in Heavy Section Steel Plates and Welds, ORNL4871, June 1973.

27. P. B. Crosley and E. J. Ripling, Materials Research Laboratory, Inc., Glenwood, Ill., Crack Arrest in an Increasing K-Field, HSSTP-TR-27, January 1973.

28. P. V. Marcal, P. M. Stuart, and R. S. Bettes, Brown University, Providence, R.I., Elastic Plastic Behavior of a Longitudinal Se: zi-Elliptic Crack in a Thick Pressure Vessel, HSSTP-TR-28, June 1973.

29. W. J. Stelzman, R. G. Berggren, and T. N. Jones, Oak Ridge Natl. Lab., Oak Ridge, Tenn., ORNL Characterization of Heavy-Section Steel Technology Program Plates 01, 02 and 03, USNRC Report NUREG/CR-4092 (ORNL/TM-9491), April 1985.

30. Canceled.

31. J. A. Williams, Hanford Engineering Development Laboratory, Richland, Wash., The Irradiation and Temperature Dependence of Tensile and Fracture Properties of ASTM A533, Grade B, Class 1 Steel Plate and Weldment, HEDL-TME 73-75, August 1973.

32. J. M. Steichen and J. A. Williams, Hanford Engineering Development Laboratory, Richland, Wash., High Strain Rate Tensile Properties of Irradiated ASTM A533 Grade B Class 1 Pressure Vessel Steel, July 1973.

33. P. C. Riccardella and J. L. Swedlow, Westinghouse Electric Corporation, Pittsburgh, Pa., A Combined Analytical-Experimental Fracture Study of the Two Leading Theories of Elastic-Plastic Fracture (J-Integral and Equivalent Energy), WCAP-8224, October 1973.

34. R. J. Podlasek and R. J. Eiber, Battelle Columbus Laboratories, Columbus, Ohio, Final Report on Investigation of Mode III Crack Extension in Reactor Piping, December 14, 1973.

35. T. R. Mager, J. D. Landes, D. M. Moon, and V. J. McLaughlin, Westinghouse Electric Corporation, Pittsburgh, Pa., Interim Report on the Effect of Low Frequencies on the Fatigue Crack Growth Characteristics of A533 Grade B Class 1 Plate in an Environment of High-Temperature Primary Grade Nuclear Reactor Water, WCAP8256, December 1973.

36. J. A. Williams, Hanford Engineering Development Laboratory, Richland, Wash., The Irradiated Fracture Toughness of ASTM A533, Grade B, Class 1 Steel Measured with a Four-Inch-Thick Compact Tension Specimen, HEDL-TME 75-10, January 1975. 
37. R. H. Bryan, J. G. Merkle, M. N. Raftenberg, G. C. Robinson, and J. E. Smith, Oak Ridge Natl. Lab., Oak Ridge, Tenn., Test of 6-Inch-Thick Pressure Vessels. Series 2: Intermediate Test Vessels V-3, V-4, and V-6, ORNL-5059, November 1975.

38. T. R. Mager, S. E. Yanichko, and L. R. Singer, Westinghouse Electric Corporation, Pittsburgh, Pa., Fracture Toughness Characterization of HSST Iniermediate Pressure Vessel Material, WCAP-8456, December 1974.

39. J. G. Merkle, G. D. Whitman, and R. H. Bryan, Oak Ridge Natl. Lab., Oak Ridge, Tenn., An Evaluation of the HSST Program Intermediate Pressure Vessel Tests in Terms of Light-Water-Reactor Pressure Vessel Safety, ORNL/TM-5090, November 1975.

40. J. C. Merkle, G. C. Robinson, P. P. Holz, J. E. Smith, and R. H. Bryan, Oak Ridge Natl. Lab., Oak Ridge, Tenn., Test of 6-In.-Thick Pressure Vessels. Series 3: Intermediate Test Vessel V-7, USNRC Report ORNL/NUREG-1, August 1976.

41. J. A. Davidson, L. J. Ceschini, R. P. Shogan, and G. V. Rao, Westinghouse Electric Corporation, Pittsburgh, Pa., The Irradiated Dynamic Fracture Toughness of ASTM A533, Grade B, Class 1 Steel Plate and Submerged Arc Weldment, WCAP-8775, October 1976.

42. R. D. Cheverton, Oak Ridge Natl. Lab., Oak Ridge, Tenn., Pressure Vessel Fracture Studies Pertaining to a PWR LOCA-ECC Thermal Shock: Experiments TSE-1 and TSE-2, USNRC Report ORNL/NUREG/TM-31, September 1976.

43. J. G. Merkle, G. C. Robinson, P. P. Holz, and J. E. Smith, Oak Ridge Natl. Lab., Oak Ridge, Tenn., Test of 6-In.-Thick Pressure Vessels. Series 4: Intermediate Test Vessels V-5 and V-9 with Inside Nozzle Corner Cracks, USNRC Report ORNL/NUREG-7, August 1977.

44. J. A. Williams, Hanford Engineering Development Laboratory, Richland, Wash., The Ductile Fracture Toughness of Heavy Section Steel Plate, USNRC Report NUREG/CR0859, September 1979.

45. R. H. Bryan, T. M. Cate, P. P. Holz, T. A. King, J. G. Merkle, G. C. Robinson, G. C. Smith, J. E. Smith, and G. $\Gamma$ hitman, Oak Ridge Natl. Lab., Oak Ridge, Tenn., Test of 6-in.-Thick Pressure Vessels. Series 3: Intermediate Test Vessel V-7A Under Sustained Loading, USNRC Report ORNL/NUREG-9, February 1978.

46. R. D. Cheverton and S. E. Bolt, Oak Ridge Natl. Lab., Oak Ridge, Tenn., Pressure Vessel Fracture Studies Pertaining to a PWR LOCA-ECC Thermal Shock: Experiments TSE-3 and TSE-4 and Update of TSE-1 and TSE-2 Analysis, USNRC Report ORNL/NUREG-22, December 1977.

47. D. A. Canonico, Oak Ridge Natl. Lab., Oak Ridge, Tenn., Significance of Reheat Cracks to the Integrity of Pressure Vessels for Light-Water Reactors, USNRC Rcport ORNL/NUREG-15, July 1977.

48. G. C. Smith and P. P. Holz, Oak Ridge Natl. Lab., Oak Ridge, Tenn., Repair Weld Induced Residual Stresses in Thick-Walled Steel Pressure Vessels, USNRC Report NUREG/CR-0093 (ORNL/NUREG/TM-153), June 1978. 
49. P. P. Holz and S. W. Wismer, Oak Ridge Natl. Lab., Oak Ridge, Tenn., Half-Bead (Temper) Repair Welding for HSST Vessels, USNRC Report NUREG/CR-0113 (ORNL/NUREG/TM-177), June 1978.

50. G. C. Smith, P. P. Holz, and W. J. Stelzman, Oak Ridge Natl. Lab., Oak Ridge, Tenn., Crack Extension and Arrest Tests of Axially Flawed Steel Model Pressure Vessels, USNRC Report NUREG/CR-0126 (ORNL/NUREG/TM-196), October 1978.

51. R. H. Bryan, P. P. Holz, J. G. Merkle, G. C. Smith, J. E. Smith, and W. J. Stelzman, Oak Ridge Natl. Lab., Oak Ridge, Tenn., Test of 6-in.-Thick Pressure Vessels. Series 3: Intermediate Test Vessel V-7B, USNRC Report NUREG/CR-0309 (ORNL/NUREG38), October 1978.

52. R. D. Cheverton, S. K. Iskander, and S. E. Bolt, Oak Ridge Natl. Lab., Oak Ridge, Tenn., Applicability of LEFM to the Analysis of PWR Vessels Under LOCA-ECC Thermal Shock Conditions, USNRC Report NUREG/CR-0107 (ORNL/NUREG-40), October 1978.

53. R. H. Bryan, D. A. Canonico, P. P. Holz, S. K. Iskander, J. G. Merkle, J. E. Smith, and W. J. Stelzman, Oak Ridge Natl. Lab., Oak Ridge, Tenn., Test of 6-in.-Thick Pressure Vessels, Series 3: Intermediate Test Vessel V-8, USNRC Reprtt NUREG/CR-0675 (ORNL/ NUREG-58), December 1979.

54. R. D. Cheverton and S. K. Iskander, Oak Ridge Natl. Lab., Oak Ridge, Tenn., Application of Static and Dynamic Crack Arrest Theory to TSE-4, USNRC Report NUREG/CR-0767 (ORNL/NUREG-57), June 1979.

55. J. A. Williams, Hanford Engineering Development Laboratory, Richland, Wash., Tensile Properties of Irradiated and Unirradiated Welds of A533 Steel Plate and A508 Forgings, USNRC Report NUREG/CR-1158 (ORNL/Sub/79-50917/2), July 1979.

56. K. W. Carlson and J. A. Williams, Hanford Engineering Development Laboratory, Richland, Wash., The Effect of Crack Length and Side Grooves on the Ductile Fracture Toughness Properties of ASTM A533 Steel, USNRC Report NUREG/CR-1171 (ORNL/Sub/79-50917/3), October 1979.

57. P. P. Holz, Oak Ridge Natl. Lab., Oak Ridge, Tenn., Flaw Preparations for HSST Program Vessel Fracture Mechanics Testing; Mechanical-Cyclic Pumping and Electron-Beam Weld-Hydrogen Charge Cracking Schemes, USNRC Report NUREG/CR-1274 (ORNL/NUREG/TM-369), May 1980.

58. S. K. Iskander, Computer Sciences Div., Union Carbide Corp. Nuclear Div., Oak Ridge, Tenn., Two Finite Element Techniques for Computing Mode I Stress Intensity Factors in Two- or Three-Dimensional Problems, USNRC Report NUREG/CR-1499 (ORNL/NUREG/CSD/TM-14), February 1981.

59. P. B. Crosley and E. J. Ripling, Materials Research Laboratory, Glenwood, Ill., Development of a Standard Test for Measuring $K_{I a}$ with a Modified Compact Specimen, USNRC Report NUREG/CR-2294 (ORNL/Sub/81-7755/1), August 1981.

60. S. N. Atluri, B. R. Bass, J. W. Bryson, and K. Kathiresan, Computer Sciences Div., Oak Ridge Gaseous Diffusion Plant, Oak Ridge, Tenn., NOZ-FLAW: A Finite Element 
Program for Direct Evaluation of Stress Intensity Factors for Pressure Vessel NozzleCorner Flaws, USNRC Report NUREG/CR-1843 (ORNL/NUREG/CSD/TM-18), March 1981.

61. A. Shukla, W. L. Fourney, and G. R. Irwin, University of Maryland, College Park, Md., Study of Energy Loss and Its Mechanisms in Homalite 100 During Crack Propagation and Arrest, USNRC Report NUREG/CR-2150 (ORNL/Sub/79-7778/1), August 1981.

62. S. K. Iskander, R. D. Cheverton, and D. G. Ball, Oak Ridge Natl. Lab., Oak. Ridge, Tenn., OCA-I, A Code for Calculating the Behavior of Flaws on the Inner Surface of a Pressure Vessel Subjected to Temperature and Pressure Transients, USNRC Report NUREG/CR-2113 (ORNL/NUREG-84), August 1981.

63. R. J. Sanford, R. Chona, W. L. Fourney, and G. R. Irwin, University of Maryland, College Park, Md., A Photoelastic Study of the Influence of Non-Singular Stresses in Fracture Test Specimens, USNRC Report NUREG/CR-2179 (ORNL/Sub/79-7778/2), August 1981.

64. B. R. Bass, S. N. Atluri, J. W. Bryson, and K. Kathiresan, Cak Ridge Natl. Lab., Oak Ridge, Tenn., OR-FLAW: A Finite Element Program for Direct Evaluation of $K$ Faciors for User-Defined Flaws in Plate, Cy!inders, and Pressure-Vessel Nozzle Corners, USNRC Report NUREG/CR-2494 (ORNL/CSD/TM-165), April 1982.

65. B. R. Bass and J. W. Bryson, Oak Ridge Natl. Lab., Oak Ridge Tenn., ORMGEN-3D: A Finite Element Mesh Generator for 3-Dimensional Crack Geometries, USNRC Report NUREG/CR-2997, Vol. 1 (ORNL/TM-8527/V1), December 1982.

66. B. R. Bass and J. W. Bryson, Oak Ridge Natl. Lab., Oak Ridge, Tenn., ORVIRT: A Finite Element Program for Energy Release Rate Calculations for 2-Dimensional and 3-Dimensional Crack Models, USNRC Report NUREG/CR-2997, Vol. 2 (ORNL/TM8527/V2), February 1983.

67. R. D. Cheverton, S. K. Iskander, and D. G. Ball, Oak Ridge Natl. Lab., Oak Ridge, Tenn., PWR Pressure Vessel Integrity During Overcooling Accidents: A Parametric Analysis, USNRC Report NUREG/CR-2895 (ORNL/TM-7931), February 1983.

68. D. G. Ball, R. D. Cheverton, J. B. Drake, and S. K. Iskander, Oak Ridge Natl. Lab., Oak Ridge, Tenn., OCA-II, A Code for Calculating Behavior of 2-D and 3-D Surface Flaws in a Pressure Vessel Subjected to Temperature and Pressure Transients, USNRC Report NUREG/ CR-3491 (ORNL-5934), February 1984.

69. A. Sautcr, R. D. Cheverton, and S. K. Iskander, Oak Ridge Natl. Lab., Oak Ridge, Tenn., Modification of OCA ! for Application to a Reactor Pressure Vessel with Cladding on the Inner Surface, USNRC Report NUREG/CR-3155 (ORNL/TM-8649), May 1983.

70. R. D. Cheverton and D. G. Ball, Martin Marietta Energy Systems, Inc., Oak Ridge Natl. Lab., Oak Ridge, Tenn., OCA-P, A Deterministic and Probabilistic Fracture-Mechanics Code for Application to Pressure Vessels, USNRC Rcport NUREG/CR-3618 (ORNL5991), May 1984. 
71. J. G. Merkle, Martin Marietta Energy Systems, Inc., Oak Ridge Natl. Lab., Oak Ridge, Tenn., An Examination of the Size Effects and Data Scatter Observed in Small Specimen Cleavage Fracture Toughness Testing, USNRC Report NUREG/CR-3672 (ORNL/TM9088), April 1984.

72. C. E. Pugh et al., Martin Marietta Energy Systems, Inc., Oak Ridge Natl. Lab., Oak Ridge, Tenn., Heavy-Section Steel Technology Program-Five-Year Plan FY 19831987, USNRC Report NUREG/CR-3595 (ORNL/TM-9008), April 1984.

73. D. G. Ball, B. R. Bass, J. W. Bryson, R. D. Cheverton, and J. B. Drake, Martin Marietta Energy Systems, Inc., Oak Ridge Natl. Lab., Oak Ridge, Tenn., Stress Intensity Factor Influence Coefficients for Surface Flaws in Pressure Vessels, USNRC Report NUREG/CR-3723 (ORNL/CSD/TM-216), February 1985.

74. W. R. Corwin, R. G. Berggren, and R. K. Nanstad, Martin Marietta Energy Systems, Inc., Oak Ridge Natl. Lab., Oak Ridge, Tenn., Charpy Toughness and Tensile Properties of Neutron Irradiated Stainless Steel Submerged-Arc Weld Cladding Overlay, USNRC Report NUREG/CR-3927 (ORNL/TM-9309), September 1984.

75. C. W. Schwartz, R. Chona, W. L. Fourney, and G. R. Irwin, University of Maryland, College Park, Md., SAMCR: A Two-Dimensional Dynamic Finite Element Code for the Stress Analysis of Moving CRacks, USNRC Report NUREG/CR-3891 (ORNL/Sub/797778/3), November 1984.

76. W. R. Corwin, G. C. Robinson, R. K. Nanstad, J. G. Merkle, R. G. Berggren, G. M. Goodwin, R. L. Swain, and T. D. Owings, Martin Marietta Energy Systems, Inc., Oak Ridge Natl. Lab., Oak Ridge, Tenn., Effects of Stainless Steel Weld Overlay Cladding on the Structural Integrity of Flawed Steel Plates in Bending, Series 1, USNRC Report NUREG/CR.4015 (ORNL.TM-9390), April 1985.

77. R. H. Bryan, B. R. Bass, S. E. Bolt, J. W. Bryson, D. P. Edmonds, R. W. McCulloch, J. G. Merkle, R. K. Nanstad, G. C. Robinson, K. R. Thoms, and G. D. Whitman, Martin Marietta Energy Systems, Inc., Oak Ridge Natl. Lab., Oak Ridge, Tenn., PressurizedThermal-Shock Test of 6-in.-Thick Pressure Vessels. PTSE-1: Investigation of Warm Prestressing and Upper-Shelf Arrest, USNRC Report NUREG/CR-4106 (ORNL-6135), April 1985.

78. R. D. Cheverton, D. G. Ball, S. E. Bolt, S. K. Iskander, and R. K. Nanstad, Martin Marietta Energy Systems, Inc., Oak Ridge Natl. Lab., Oak Ridge, Tenn., Pressure Vessel Fracture Studies Pertaining to the PWR Thermal-Shock Issue: Experiments TSE-5, TSE-5A, and TSE-6, USNRC Report NUREG/CR-4249 (ORNL-6163), June 1985.

79. R. D. Cheverton, D. G. Ball, S. E. Bolt, S. K. Iskander, and R. K. Nanstad, Martin Marictta Energy Systems, Inc., Oak Ridge Natl. Lab., Oak Ridge, Tenn., Pressure Vessel Fracture Studies Pertaining to the PWR Thermal-Shock Issue: Experiment TSE7, USNRC Report NUKEG/CR-4304 (ORNL-6177), August 1985.

80. R. H. Bryan, B. R. Bass, S. E. Bolt, J. W. Bryson, J. G. Merkle, R. K. Nanstad, and G. C. Robinson, Martin Marictta Energy Systems, Inc., Oak Ridge Natl. Lab., Oak Ridge, Tenn., Test of 6-in.-Thick Pressure Vessels. Series 3: Intermediate Test Vessel 
V-8A-Tearing Behavior of Low Upper-Shelf Material, USNRC Report NUREG/CR4760 (ORNL-6187), May 198\%.

81. R. D. Cheverton and D. G. Ball, Martin Marietta Energy Systems, Inc., Oak Ridge Natl. Lab., Oak Ridge, Tenn., A Parametric Study of PWR Pressure Vessel Integrity During Overcooling Accidents, Considering Both 2-D and 3-D Flaws, USNRC Report NUREG/CR-4325 (ORNL/TM-9682), August 1985.

82. E. C. Rodabaugh, E. C. Rodabaugh Associates, Inc., Hilliard, Ohio, Comments on the Leak-Before-Break Concept for Nuclear Power Plant Piping Systems, USNRC Report NUREG/CR-4305 (ORNL/Sub/82-22252/3), August 1985.

83. J. W. Bryson, Martin Marietta Energy Systems, Inc., Oak Ridge Natl. Lab., Oak Ridge, Tenn., ORVIRT.PC: A 2-D Finite Element Fracture Analysis Program for $a$ Microcomputer, USNRC Report NUREG/CR-4367 (ORNL-6208), October 1985.

84. D. G. Ball and R. D. Cheverton, Martin Marietta Energy Systems, Inc., Oak Ridge Natl. Lab., Oak Ridge, Tenn., Aaaptation of OCA-P, A Probabilistic Fracture-Mechanics Code, to a Personal Computer, USNRC Report NUREG/CR-4468 (ORNL/CSD/TM233), January 1986.

85. J. W. Bryson and B. R. Bass, Martin Marietta Energy Systems, Inc., Oak Ridge Natl. Lab., Oak Ridge, Tenn., ORMGEN.PC: A Microcomputer Program for Automatic Mesh Generation of 2-D Crack Geometries, USNRC Report NUREG/CR-4475 (ORNL-6250), March 1986.

86. G. D. Whitman, Martin Marietta Energy Systems, Inc., Oak Ridge Natl. Lab., Oak Ridge, Tenn., Historical Summary of the Heavy-Section Steel Technology Program and Some Related Activities in Light-Water Reactor Pressure Vessel Safety Research, USNRC Report NUREG/CR-4489 (ORNL-6259), March 1986.

87. C. Inversini and J. W. Bryson, Martin Marietta Energy Systems, Inc., Oak Ridge Natl. Lab., Oak Ridge, Tenn., ORPLOT PC: A Graphic Utility for ORMGEN.PC and ORVIRT.PC, USNRC Report NUREG/CR-4633 (ORNL-6291), June 1986.

88. J. J. McGowan, R. K. Nanstad, and K. R. Thoms, Martin Marietta Energy Systems, Inc., Oak Ridge Natl. Lab., Oak Ridge, Tenn., Characterization of Irradiated CurrentPractice Welds and A533 Grade B Class 1 Plate for Nuclear Pressure Vessel Service. USNRC Report NUREG/CR-4880 (ORNL/TM-10387), July 1988.

89. K. V. Cook and R. W. McClung, Martin Marietta Energy Systems, Inc., Oak Ridge Natl. Lab., Oak Ridge, Tenn., Flaw Density Examinations of a Clod Boiling Water Reactor Pressure Vessel Segment, USNRC Report NUREG/CR-4860 (ORNL/TM10364), April 1987.

90. D. J. Naus, B. R. Bass, C. E. Pugh, R. K. Nanstad, J. G. Merkle, W. R. Corwin, and G. C. Robinson, Martin Marietta Energy Systems, Inc., Oak Ridge Natl. Lab., Oak Ridge, Tenn., Crack-Arrest Behavior in SEN Wide Plates of Quenched and Tempered A 533 Grade B Steel Tested Under Nonisothermal Conditions, USNRC Report NUREG/CR-4930 (ORNL-6388), August 1987. 
91. D. B. Barker, R. Chona, W. L. Fourney, and G. R. Irwin, University of Maryland, College Park, Md., A Report on the Round Robin Program Conducted to Evaluate the Proposed ASTM Standard Test Method for Determining the Plane Strain Crack Arrest Fracture Toughness, $K_{l a}$, of Ferritic Materials, USNRC Report NUREG/CR-4966 (ORNL/Sub/79-7778/4), January 1988.

92. W. H. Bamford, Westinghouse Electric Corporation, Pittsbuigh, Pa., A Summary of Environmentally Assisted Crack-Growth Studies Performed at Westinghouse Electric Corporation Under Funding from the Heavy-Section Steel Technology Program, USNRC Report NUREG/CR-5020 (ORNL/Sub/82-21598/1), May 1988.

93. R. H. Bryan, B. R. Bass, S. E. Bolt, J. W. Bryson, W. R. Corwin, J. G. Merkle, R. K. Nanstad, and G. C. Robinson, Martin Marietta Energy Systems, Inc., Oak Ridge Nati. Lab., Oak Ridge, Tenn., Pressurized-Thermal-Shock Test of 6-in.-Thick Pressure Vessels. PTSE-2: Investigation of Low Tearing Resistance and Warm Prestressing, USNRC Report NUREG/CR-4888 (ORNL-6377), December 1987.

94. J. H. Giovanola and R. W. Klopp, SRI International, Menlo Park, Calif., Viscoplastic Stress-Strain Characterization of A533B Class 1 Steel, USNRC Report NUREG/CR5066 (ORNL/Sub/87-SA193/1), September 1989.

95. L. F. Miller et al., Martin Marietta Energy Systems, Inc., Oak Ridge Natl. Lab., Oak Ridge, Tenn., Neutron Exposure Parameters for the Metallurgical Test Specimens in the Fifth Heavy-Section Steel Technology Irradiation Series Capsules, USNRC Report NUREG// CR-5019 (ORNL/TM-10582), March 1988.

96. Canceled.

97. D. J. Naus, J. Keeney-Walker, and B. R. Bass, Martin Marietta Energy Systems, Inc.. Oak Ridge Natl. Lab., Oak Ridge, Tenn., High-Temperature Crack-Arrest Behavior in 152-mm-Thick SEN Wide Plates of Quenched and Tempered A 533 Grade B Steel, USNRC Report NUREG/CR-5330 (ORNL/TM-11083), April 1989.

98. K. V. Cook, R. A. Cunningham, Jr., and R. W. McClung, Martin Marietta Energy Systems, Inc., Oak Ridge Natl. Lab., Oak Ridge, Tenn., Detection and Characterization of Indications in Segments of Reactor Pressure Vessels, USNRC Report NUREG/CR5322 (ORNL/TM-1 1072), August 1989.

99. R. D. Cheverton, W. E. Pennell, G. C. Robinson, and R. K. Nanstad, Martin Marietta Energy Systems, Inc., Oak Ridge Natl. Lab., Oak Ridge, Tenn., Impact of Radiation Embrittlement on Integrity of Pressure Vessel Supports for Two PWR Plants, NUREG/CR-5320 (ORNL/TM-10966), February 1989.

100. D. J. Naus, J. Keeney-Walker, B. R. Bass, S. K. Iskander, R. J. Fields, R. deWitt, and S. R. Low III, Martin Marietta Energy Systems, Inc., Oak Ridge Natl. Lab., Oak Ridge. Tenn., SEN Wide-Plate Crack-Arrest Tests Utilizing A 533 Grade B Class 1 Material: WP-CE Test Series, USNRC Report NUREG/CR-5408 (GRNL/TM-11269), November 1989.

101. D. J. Naus, J. Keeney-Walker, B. R. Bass, S. K. Iskander, R. J. Fields, R. deWitt, and S. R. Low III, Martin Marietta Energy Systems, Inc., Oaik Ridge Natl. Lab., Oak Ridge, Tenn., High Temperature Crack-Arrest Tests Usıng 152-mm-Thick SEN Wide Plates of 
xviii

Low Upper-Shelf Base Material: Tests WP-2.2 and WP-2.6, USNRC Report NUREG/CR-5450 (ORNL/TM-11352), February 1990.

102. Canceled.

103. D. J. Naus, .. Keeney-Walker, B. R. Bass, G. C. Robinson, S. K. Iskander, D. J. Alexander, R. J. Fields, R. deWitt, S. R. Low, C. W. Schwartz, and I.-B. Johansson, Martin Marietta Energy Systems, Inc., Oak Ridge Natl. Lab., Oak Ridge, Tenn., CrackArrest Behavior in SEN Wide Plates of Low Upper-Shelf Base Metal Tested Under Nonisothermal Conditions: WP-2 Series, USNRC Report NUREG/CR-5451 (ORNL6584), August 1990.

104. T. L. Dicksor, R. D. Cheverton, and D. K. Shum, Martin Marietta Energy Systems, Inc., Oak Ridge Natl. Lab., Oak Ridge, Tenn., Inclusion of Unstable Ductile Tearing and Extrapolated Crack-Arrest Toughness Data in PWR Vessel Integrity Assessment, USNRC Report NUREG/CR-5473 (ORNL/TM-11450), May 1990.

105. T. J. Theiss, Martin Marietta Energy Systems, Inc., Oak Ridge Natl. Lab., Oak Ridge, Tenn., Recommendations for the Shallow-Crack Fracture Toughness Testing Task Within the HSST Program, USNRC Report NUREG/CR-5554 (ORNL/TM-11509), September 1990.

106. J. G. Merkle, Martin Marietta Energy Systems, Inc., Oak Ridge Natl. Lab., Oak Ridge, Tenn., An Overview of the Low Upper Shelf Toughness Safety Margin Issue, USNRC Report NUREG/CR-5552 (ORNL/TM-11314), August 6, 1990.

107. D. K. M. Shum, J. G. Merkle, J. Keeney-Walker, and B. R. Bass, Martin Marietta Energy Systems, Inc., Oak Ridge Natl. Lab., Oak Ridge, Tenn., Analytical Studies of Transverse Strain Effects on Fracture Toughness for Circumferentially Oriented Cracks, USNRC Report NUREG/CR-5592 (ORNI./TM-11581), April 1991.

108. J. D. Landes, Extrapolation of the J-R Curve for Predicting Reactor Vessel Integrity, USNRC Report NUREG/CR-5650 (ORNL/Sub/89-99732/1) (to be published).

109. J. Keeney-Walker, B. R. Bass, and J. D. Landes, Martin Marietta Energy Systems, Inc., Oak Ridge Natl. Lab., Oak Ridge, Tenn., An Investigation of Crack-Tip Stress-Field Criteria for Predicting Cleavage-Crack Initiation, USNRC Report NUREG/CR-5651 (ORNL/TM-11692) (to be published).

110. G. R. Irwin, University of Maryland, Use of Thickness Reduction to Estimate Values of $K$, USNRC Report NUREG/CR-5697 (ORNL/Sub/79-7778/5), prepared at University of Maryland for Martin Marietta Energy Systems, Inc., Oak Ridge Natl. Lab., Oak Ridge, Tenn. (to be published).

111. Pedro Albrecht, University of Maryland, Limit Pressure Analysis of PTSE-2 Vessel, USNRC Report NUREG/CR-5698 (ORNL/Sub/79-7778/6), prepared at University oi Maryland for Martin Marietta Energy Systems, Inc., Oak Ridge Natl. Lab., Oak Ridge, Tenn. (tn be published).

112. James W. Dally, William L. Fourney, and George B. Irwin, University of Maryland, Lower-Bound Initiation Toughness with a Modified-Charpy Specimen, USNRC Report NUREG/CR-5703 (ORNL/Sub/79-7778/7), prepared at University of Maryland for 
Martin Marietta Energy 5 stems, Inc., Oak Ridge Natl. Lab., Oak Ridge, Tenn. (to be published).

113. S. K. Islander, G. C. Robinson, W. R. Corwin, B. C. Oland, D. J. Alexander, and K. V. Cook, Martin Marietta Energy Systems, Inc., Oak Ridge Natl. Lab., Oak Ridge, Tenn., Experimentai Results of Tests to Investigate Flaw Behavior of Mechanically Loaded Stainless Steel Clad Plates, USNRC Report NUREG/CR-xxxx (to be published).

114. This report. 


\title{
STATUS REPORT ON THE BEHAVIOR OF SHALLOW FLAWS IN REACTOR PRESSURE VESSELS
}

\author{
S. T. Rolfe
}

\section{BACKGROUND}

Analytical and experimental research at the University of Kansas ${ }^{1,2}$ have shown that the effect of crack length, a, on the elastic-plastic fracture toughness of structural steels is significant. Test specimens with shallow flaws have higher toughness levels than test specimens with deep flaws when both specimens are loaded to the same level of crack-opening stress, $\sigma_{y}$, at the crack tip. This higher level of toughness at fracture is caused by a loss of in-plane constraint in specimens with shallow flaws.

Comparison of two-dimensional (2-D) plane strain finite-element results of test specimens with various crack-depth to specimen-width ratios, a/ $\mathrm{W}$, showed a fundamental change in the nonlinear st: ess field at an a/W ratio of $\sim 0.15$. Specimens with shorter cracks ( $a / W=0.10$ and 0.05 ) showed yielding to the front (tension) surface behind the crack well before the formation of the plastic hinge. Specimens with deepur cracks $(\mathrm{a} / \mathrm{W} \geq 0.20)$ developed a plastic hinge before the plastic zone extended from the crack tip back to the front surface.

The analytical results were verified experimentally for an A 36 steel $\left(\sigma_{y s}=248 \mathrm{MPa}\right)$ and an A 517 steel $\left(\sigma_{y s}=690 \mathrm{MPa}\right)$. The yield strengths and strain-hardening exponents of these steels bound that of A $533 \mathrm{~B}$ steel $\left(\sigma_{\mathrm{ys}}=470 \mathrm{MPa}\right)$, which is used in the construction of reactor pressure vessels (RPVs). The experimental results for the A 36 and A 517 steels tested at the University of Kansas are presented in Fig. 1. Preliminary test results conducted at the Oak Ridge National Laboratory (ORNL) ${ }^{3}$ show that similar behavior exists for A 533 B steel (Figs. 2 and 3). The results presented in Figs. 1--3 are in terms of the elastic-plastic fracture mechanics parameter, crack-tip-opening displacement (CTOD). The CTOD parameter was used because the inherent toughness at the temperatures of interest was beyond the limits of plane-strain linear-elastic fracture mechanics $\mathrm{K}_{\mathrm{Ic}}$, yet there was no significant stable crack growth, and thus $\mathrm{J}_{\mathrm{Ic}}$ could not be measured either.

Because current RPV life assessments are strongly dependent on the ability of the vessel material to withstand load in the presence of a flaw (i.e., sufficient fracture toughness), it is important that realistic assessments of the fracture toughness of pressure vessel steels be made. The fracture toughness value used in RPV life assessments to date has been generated using deep-notch specimens. On the basis of the test results presented in Figs. 1-3 and recent finite- 

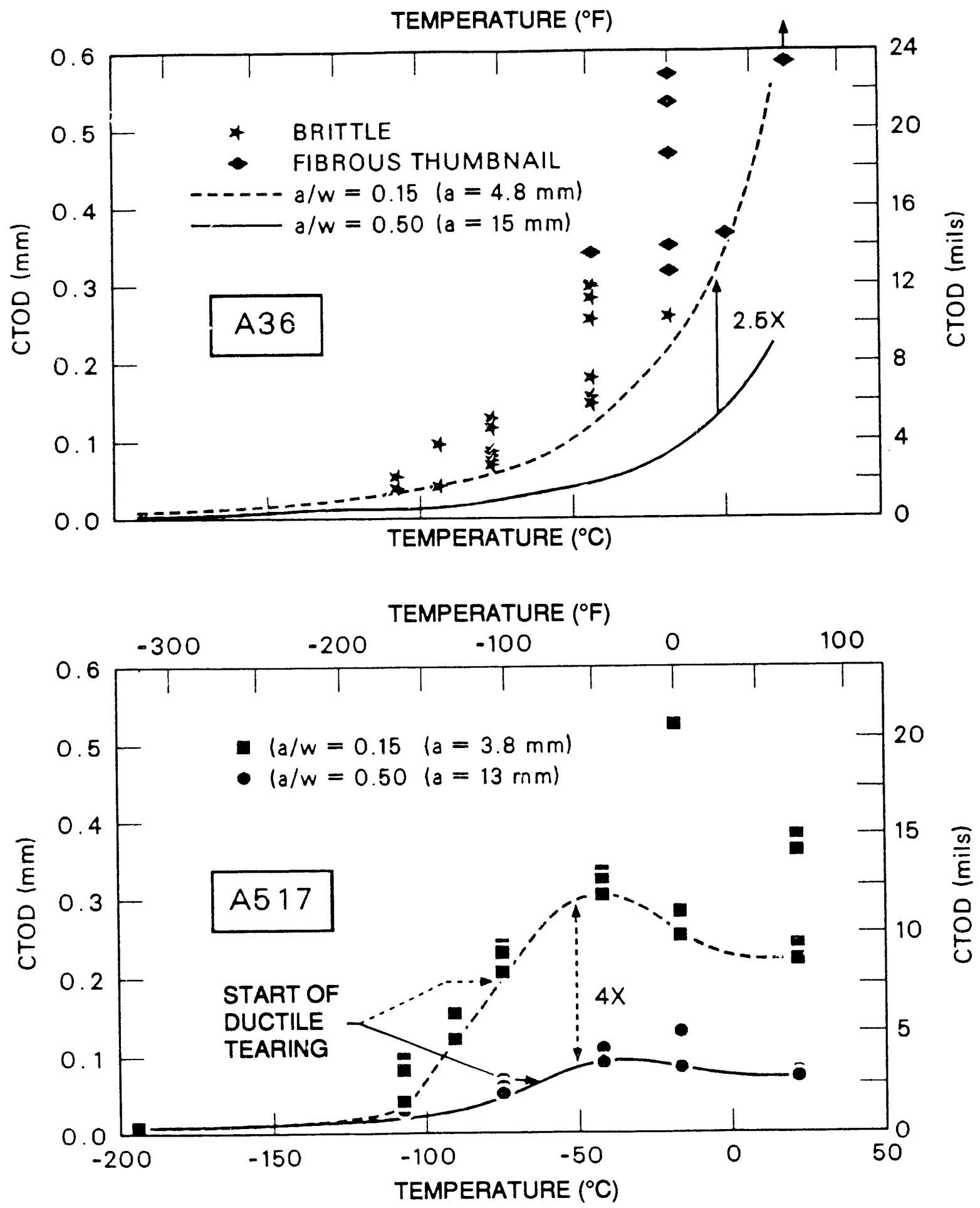

Fig. 1. Effect of a/W ratio on fracture toughness of (a) A 36 and (b) A 517 steels tested at University of Kansas. 


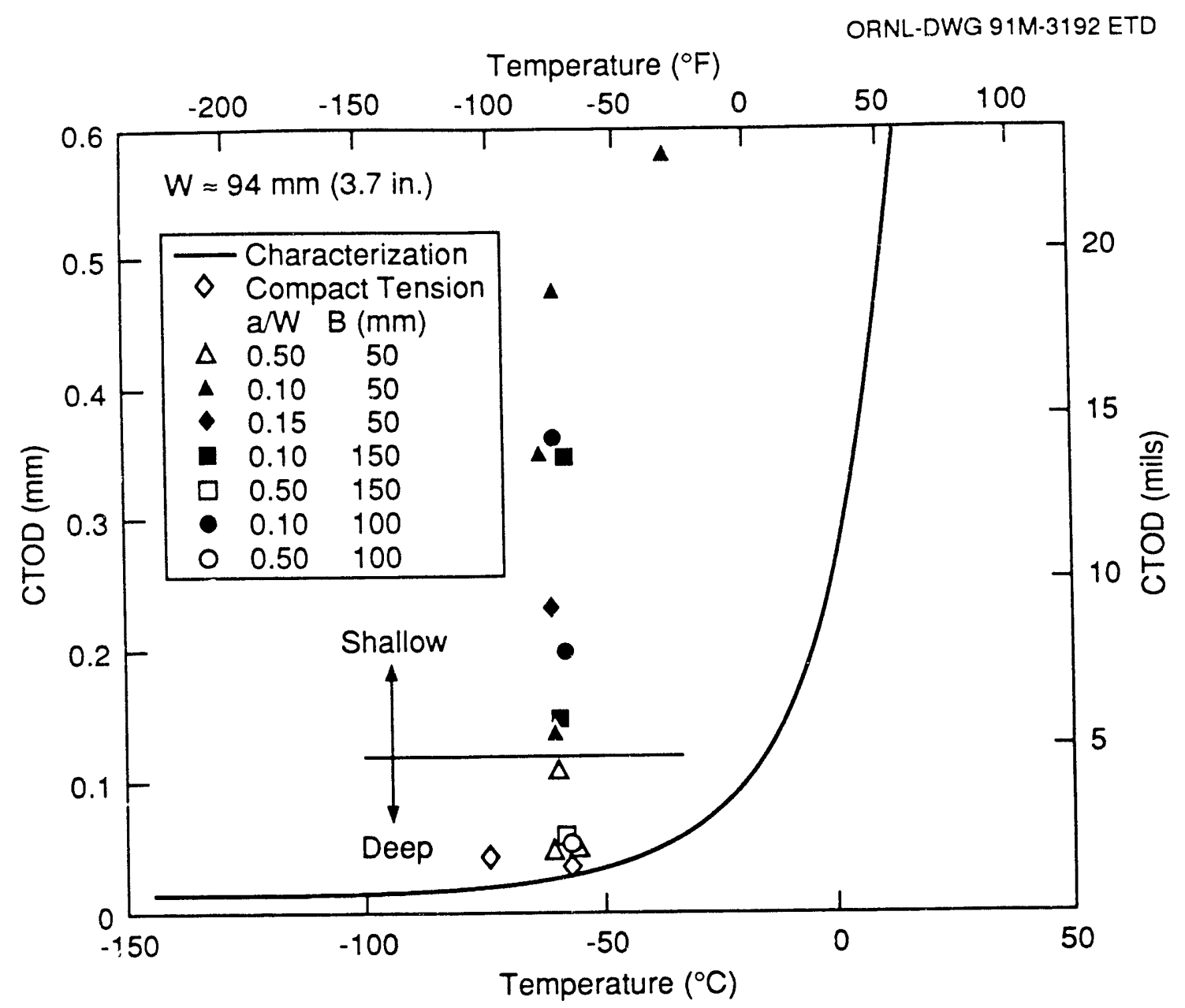

Fig. 2. Effect of crack depth on fracture toughness of A 533 B steel.

element analyses of both deep-notch and shallow-notch specimens, 1,2 it now appears that determining fracture toughness using deep-notch specimens may be an unduly conservative approach for service applications in which shallow flaws are the ones of primary interest. Therefore, the Heavy-Section Steel Technology (HSST) Program under sponsorship of the Nuclear Regulatory Commission (NRC) is investigating the influence of crack depth on the fracture toughness of RPV steel. ${ }^{4}$

The ultimate goal of the investigation is the generation of a limited number of clasticplastic fracture toughness values appropriate for shallow flaws in an RPV anid guidelines conceming the application of these data to reactor vessel life assessments. This study is not intended to be a complete experimental investigation that would result in a new design methodology. Rather, it is a limited experimental and analytical study of the behavior of shallow 


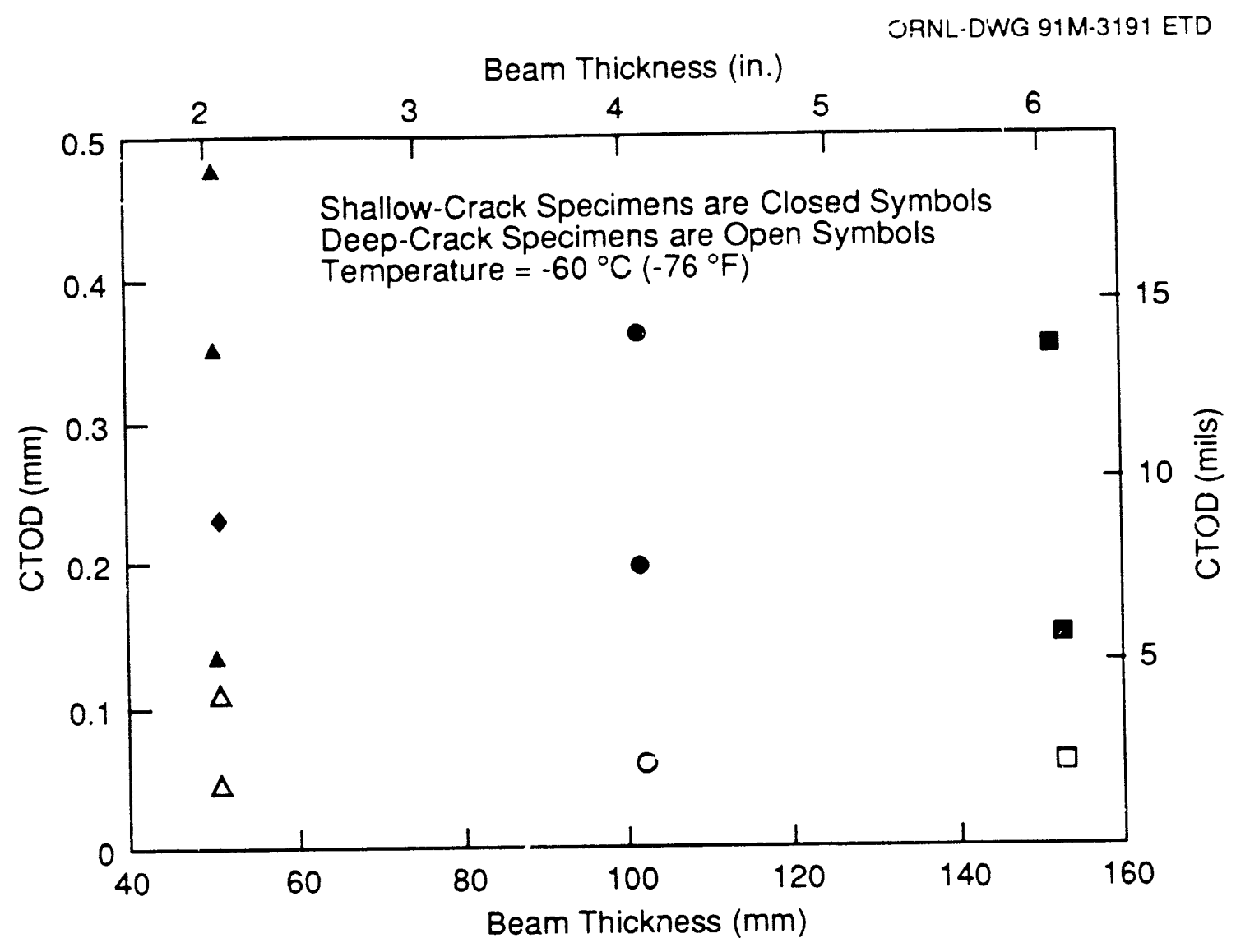

Fig. 3. Effect of specimen thickness on fracture toughness of A 533 B steel.

flaws in reactor pressure vessels. Relatively large beams are being tested $(50,100$, and $150 \mathrm{~mm}$ thick by $100 \mathrm{~min}$ deep) to simulate the stress state in a flawed RPV as closely as is practical. Crack depths, a, currently being considered range from shallow (10 to $15 \mathrm{~mm}$ ) to deep (50 mm).

Probabilistic fracture mechanics evaluations of operating nuclear facilities in the Integrated Pressurized-Thermal Shock (IPTS) studies have shown that shallow rather than deep cracks in the RPV contribute predominantly to the calculated probability of vessel failure. ${ }^{5-7}$ The dominance of shallow rather than deep flaws in the probabilistic fracture mechanics evaluations in part results from the higher density of shallow flaws assumed or predicted to exist in the vessel wall, the increased radiation damage, and the severity of the thermal shock on the vessel inner surface. IPTS studies ${ }^{5-7}$ indicate that $\sim 95 \%$ of all the flaws that are predicted to initiate during the dominant transients for the three plants considered were $25 \mathrm{~mm}$ ( 1 in.) deep or less. Thus, the enhancement of the toughness of steels used in vessels with shallow flaws could have a significant impact on the structural margin assessment of RPVs with flaws. 


\section{EXISTING METHODOLOGY}

Existing methodologies to assess the fracture toughness behavior of steels for nuclear RPVs are based in part on Sect. XI of the American Society of Mechanical Engineers (ASME) Boiler and Pressure Vessel Code. ${ }^{8}$ In the ASME Code initiation and arrest curves $\mathrm{K}_{\mathrm{Ic}}$ and $\mathrm{K}_{\mathrm{Ia}}$ are referenced to the $\mathrm{RT}_{\mathrm{NDT}}$ temperature as shown in Fig. 4 . The $\mathrm{K}_{\mathrm{Ia}}$ reference toughness curve was developed by plotting all known data (static, dynamic, and arrest values) vs the temperature relative to $\mathrm{RT}_{\mathrm{NDT}}$ and constructing a lower-level curve not transgressed by any of the data. Data ${ }^{9}$ used to develop the $\mathrm{K}_{\mathrm{Ic}}$ reference curve are presented in Fig. 5 .

Subsequent test results for small specimens, some of which were adjusted using Irwin's $\beta_{\text {Ic }}$ correction, as well as several HSST thermal-shock experiments, verify that the ASME Sect. XI reference curve is indeed a lower-bound curve ${ }^{10}$ (Fig. 6).

ORNL-DWG 91-3194 ETD

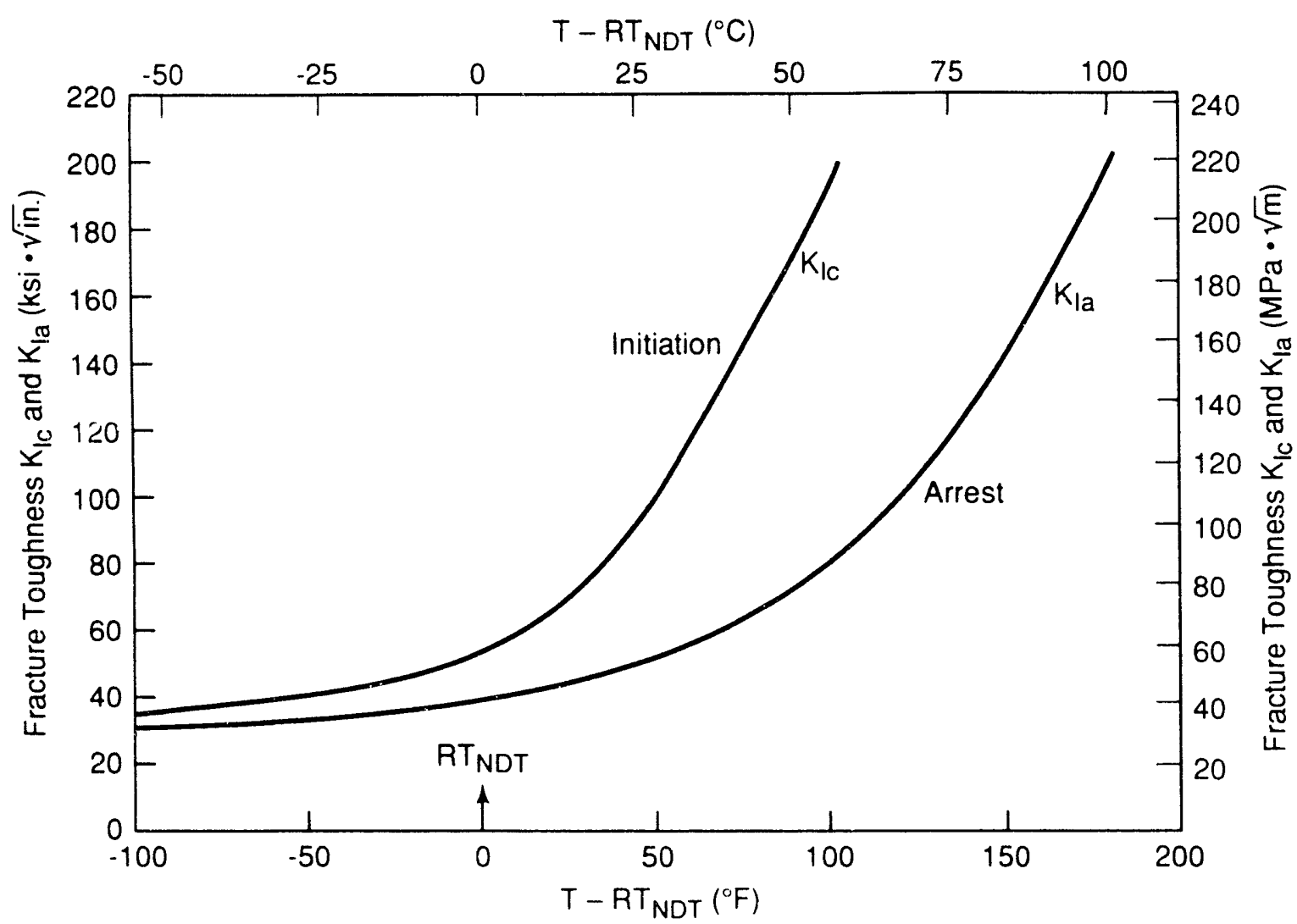

Fig. 4. Lower-bound $\mathrm{K}_{\mathrm{Ia}}$ and $\mathrm{K}_{\mathrm{Ic}}$ test data for SA 533 grade B class 1, SA 508 class 2, and SA 508 class 3 steels-ASME Sect. XI. 


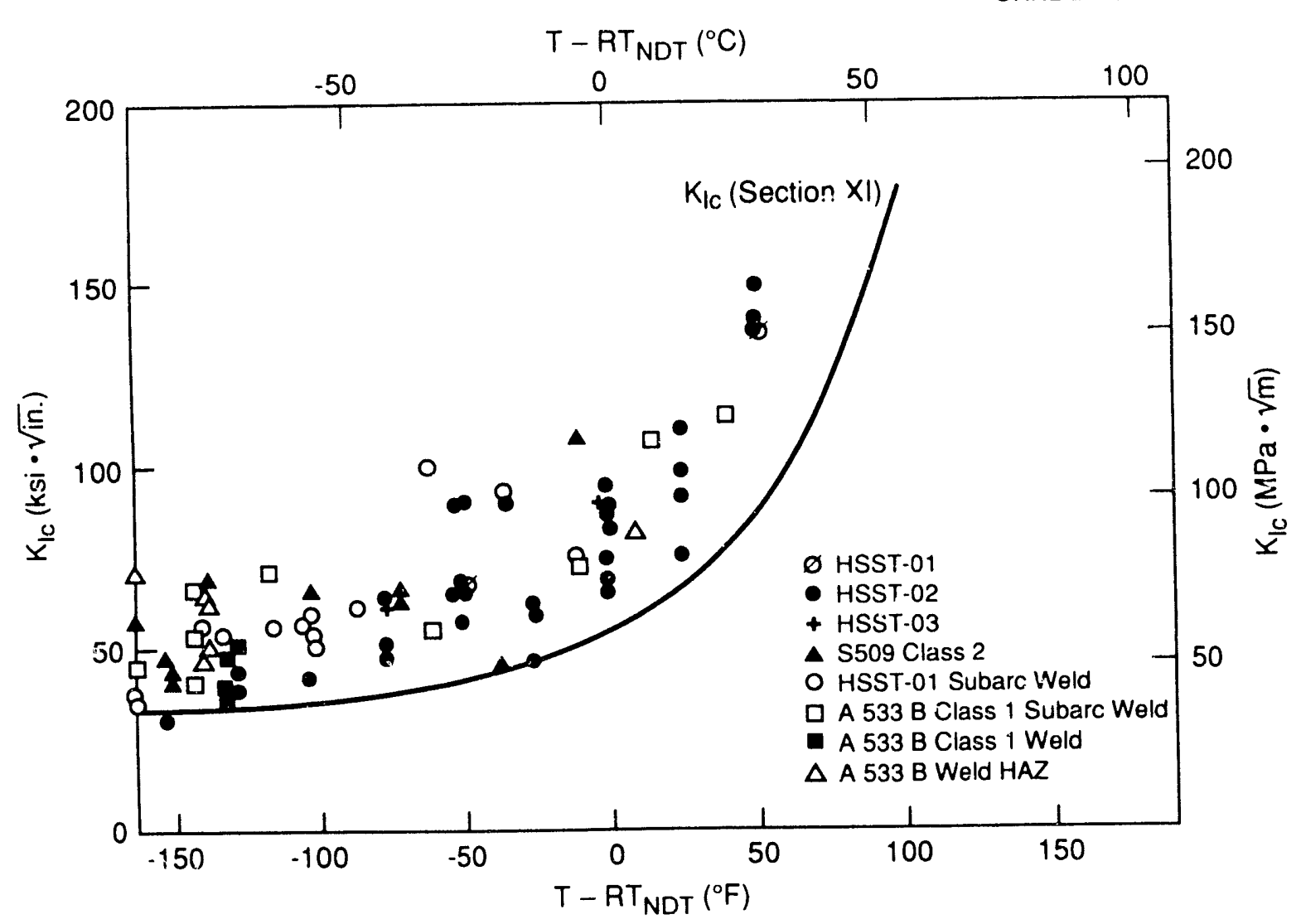

Fig. 5. K Ic reference curve with supporting data. Source: T. V. Marston, "Flaw Evaluation Procedures-Background and Applications of ASME Section XI," Appendix A-NP-719-SR, Special Report, August 1978, ASME-Section XI Task Group on Flaw Evaluation.

Use of laboratory test specimens with a/W ratios of 0.5 leads to maximum constraint in most laboratory test specimens and appears to be a conservative approach to analyzing the behavior of pressure vessel steels for nuclear reactors. Concern about PTS loading of vessels with shallow flaws has led to PTS testing of vessels as well as various analyses of the PTS problem with the objective of refining the technology used in analysis of RPV fracture margins under PTS loading.

Among the concerns during PTS loading is the indication that the majonty of possible crack initiations would originate at flaws 5 to $15 \mathrm{~mm}$ deep ( 0.2 to $0.6 \mathrm{in}$.) located on the inside of the wall; the stresses due to thermal shock would be greatest and the resistance to fracture would be lowest because of irradiation damage. Finally, the material would be at its lowest temperature because of the application of cooling water to the inner wall surface. Thus, the toughness would be at a lower level corresponding to the lower service temperature. These 5- to 


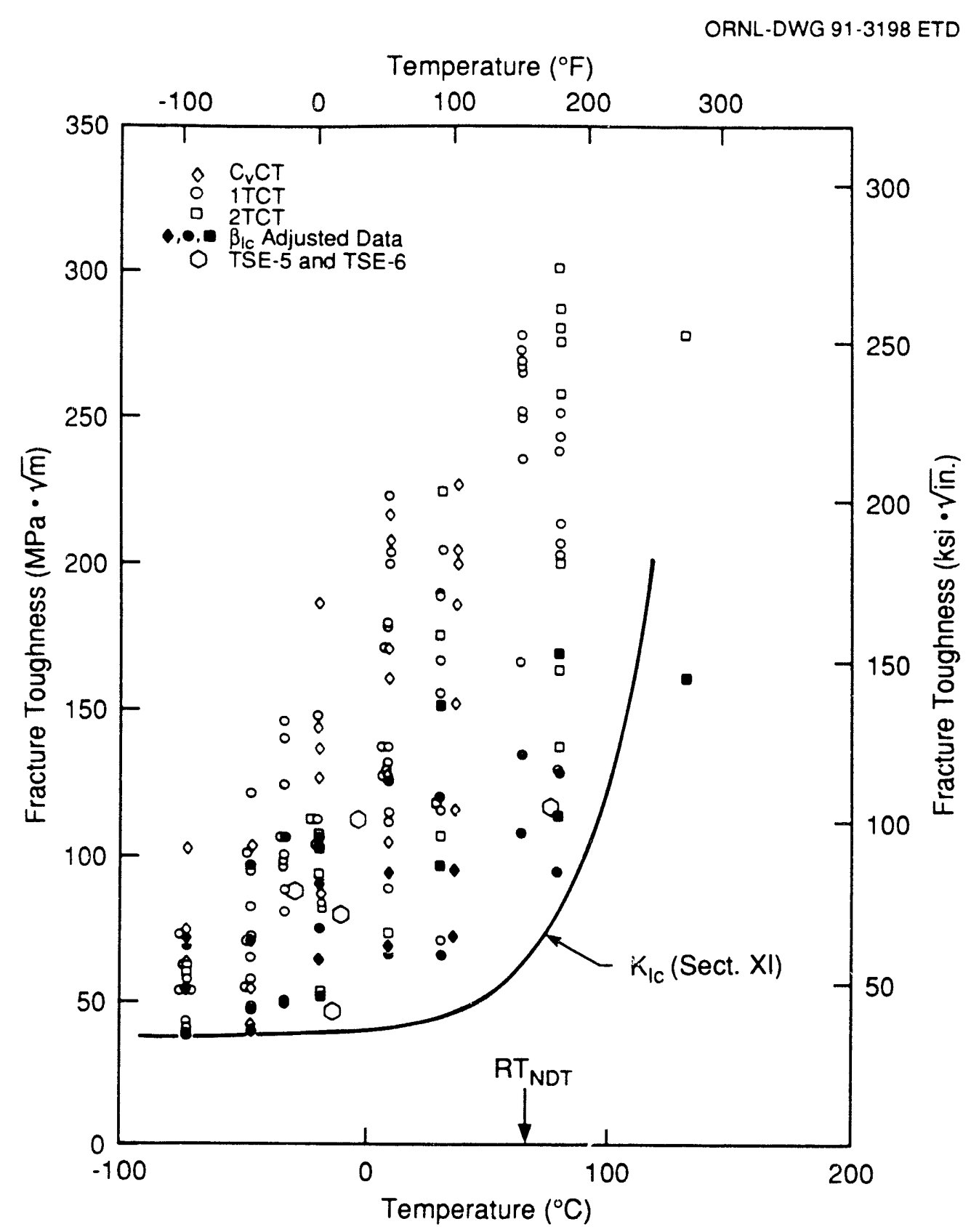

Fig. 6. Comparison of $\beta_{\text {Ic }}$ adjusted small-specimen static initiation toughness values with thick-section test results for TSE-5 and -6 materials. Source: J. G. Merkle, Martin Marictta Energy Systems, Inc., Oak Ridge Nat. Lab. "An Examination of the Size Effects and Data Scatter Observed in Small-Specimen Cleavage Fracture Toughness Testing," USNRC Report NUREG/CR-3672 (ORNL/TM-9088), April 1984.

15-mm-deep (0.2- to 0.6-in.) flaws are considered to be shallow and can be better represented by shallow-flaw data; yet the toughness values used to analyze the behavior of actual vessels subjected to PTS loading are based on results of deep-notch fracture toughness specimens. 


\section{RECOMMENDATIONS}

Preliminary test results of A 533 B stecl show an elevated CTOD toughness (Figs. 2 and 3) similar to that observed for structural stecls tested at the University of Kansas (Fig. 1). Thus, the inherent resistance to fracture initiation of A 533 B steel with shallow flaws appears to be higher than that used in the current ASME design curves based on linear-elastic fracture mechanics $\mathrm{K}_{\mathrm{Ic}}$. If this higher toughness can be transferred to a higher resistance to failure in RPV design or analysis, then the actual margin of safety in nuclear vessels with shallow flaws would be greater than is currently assumed on the basis of deep-flaw test results. Obviously, this clevation in toughness and greater resistance to fracture would be a very desirable situation, particularly for the PTS analysis in which shallow flaws are assumed to exist.

Before any advantage can be taken of this observed increase in initiation toughness, numerous factors must be analyzed to ensure the transferability of the data. Accordingly, it is recommended that the following studies be made to assess the transferability of shallow-flaw toughness test results to the structural margin assessment of RPVs with shallow flaws.

1. Obviously, the first step is to conduct shallow-flaw tests of A 533 B stecl. If the tests show no significant effect, then continued study of the possible benefits of enhanced toughness levels would be inappropriate. However, preliminary test results (Figs. 2 and 3) clearly indicate an increased toughness associated with shallow-flaw specimens compared with deep-notch specimens. Additional tests of A 533 B specimens with various crack lengths, a, should be conducted at additional temperatures to verify these preliminary results.

The A 533 B steel specimens with shallow flaws tested to date exhibit greater toughness levels than specimens with deep flaws for 50-, 100-, and 150-mm-thick (2-, 4-, and 6-in.) specimens. These large specimens are believed to be fairly reprusentative of actual vessels. Thus, the question of whether crack length, $a$, or the a/ $\mathrm{W}$ ratio controls the behavior becomes less important because crack depths of 10 and $15 \mathrm{~mm}(0.4$ and 0.6 in.) are also representative of the shallow-flaw depths believed to be present in actual vessels. The analytical phase of the program (Recommendations 2 and 3) should model full thickness vessels (c.g., $203 \mathrm{~mm}$ ) and thus help to determine the controlling parameter (a or $\mathrm{a} / \mathrm{W}$ ) for reactor vessel analysis. However, as will be discussed later in this report, crack length, a, is believed to be the primary factor, and the a/W ratio is believed to be a secondary factor.

To date, the test results have exceeded the limits of plane strain American Society for Testing and Materials (ASTM) E-399 behavior, that is, valid $K_{\text {Ic }}$ test results. Also, ASTM E813 criteria for $\mathrm{J}$-integral testing do not apply tecause in the lower transition region, $\Delta \mathrm{a} \cong 0$ and thus $\mathrm{J}_{\mathrm{Ic}}$ cannot be determined. However, it is possible that a $\mathrm{J}_{\mathrm{c}}$ value can be inferred 
experimentally from the P- $\Delta$ curve. Accordingly, use of the ASTM E-1290 CTOD parameter is necessary. However, relations do exist between CTOD, J, and $\mathrm{K}$ so that the results can be evaluated in several ways.

2. Concurrently, analytical studies that model the test specimens should be conducted to better uriderstand the reasons for the toughness elevation and to verify the experimental results. Research at the University of Kansas has shown that in the lower transition region, where cunsiderable plastic deformation and crack-tip blunting occurs prior to brittle fracture, the experimental lower-bound fracture toughness results of shallow-crack specimens are two to four times larger than the results of the deep-crack specimens in terms of CTOD at identical temperatures (Fig. 1). At equivalent $\mathrm{K}_{\mathrm{I}}$ levels in the clastic-plastic regime, finite-element analyses reveal significant differences in the crack-tip stresses between the deep- and shallowcrack specimens. The deep-crack specimens exhibit significantly higher opening-mode stresses near the crack tip compared to the shallow-crack specimens (Fig. 7). Correspondingly, at

ORNL-DWG 91.3197 ETD

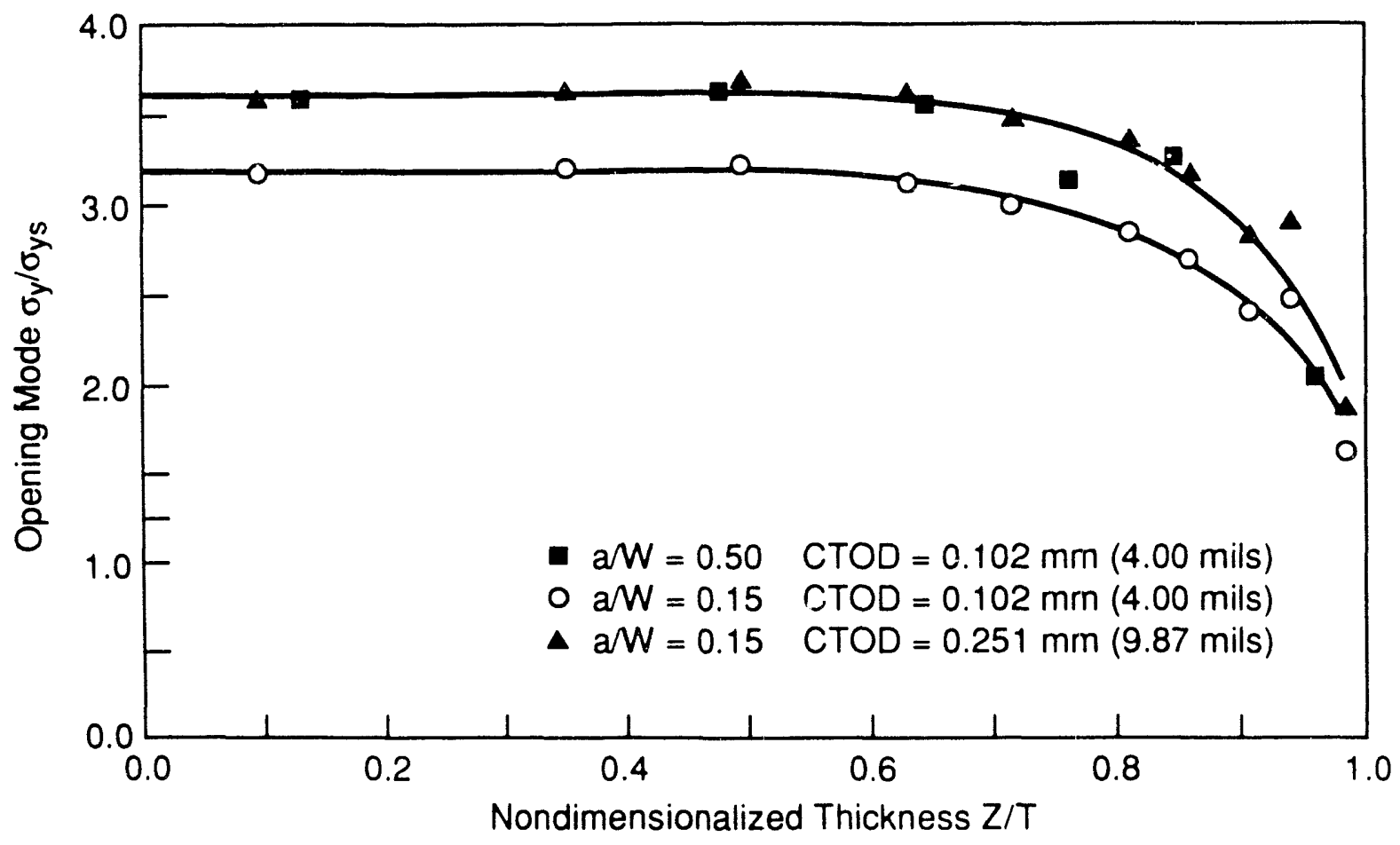

Fig. 7. Crack-opening stress distributions for 31.8 - by $31.8-\mathrm{mm}$ A 36 steel specimens. Source: W. A. Sorem, R. H. Dodds, Jr., and S. T. Rolfe, The University of Kansas, "An Analytical Comparison of Short-Crack and Deep-Crack CTOD Fracture Specimens of an A 36 Steel," WRC Bulletin 351, Welding Research Council, February 1990. 
equivalent levels of opening mode stress, the shallow-crack specimens had CTOD (and J-integral) values $\sim 2.5$ times that the of deep-crack specimen (CTOD of $0.25 \mathrm{~mm}$ compared with $0.10 \mathrm{~mm}$, respectively). The phenomenon of elevated fracture toughness associated with a shallow crack is a consequence of the relaxation of in-plane crack-tip constraint because of the proximity of the front, free surface. It is believed that loss of constraint also will take place at the inside surface of RPVs with shallow cracks. However, as noted in Recommendation 3, finite-element analyses of actual RPVs with shallow flaws should be conducted to verify this assumption.

Analytical studies of A 533 B test specimens under conditions of plane strain (maximum constraint) should serve as a good indicator of the significance of the shallow-flaw test results to be obtained as part of Recommendation 1. The elevated toughness associated with flaws representative of those existing in an RPV (e.g., 10 to $15 \mathrm{~mm}$ ) appears to exist in multiple specimen sizes (Figs. 2 and 3). The magnitude of the toughness increase also appears fairly consistent in the test data generated to date for specimens with thickness of 50,100, and $150 \mathrm{~mm}(2,4$, and $6 \mathrm{in}$.$) .$

3. Analytical studies that model portions of actual flawed RPV simulating maximum constraint (plane strain) should be made. Hopefully, the laboratory test specimens selected are sufficiently large to provide a close approxination to the constraint levels as obtained analytically under conditions of maximum constraint (plane strain). As discussed in Recommendation 5, current ORNL studies of advanced fracture methodologies should be very useful in verifying that the constraint levels in the laboratory test specimens are representative of the constraint levels in actual vessels. Again, preliminary results of specimens 50,100, and $150 \mathrm{~mm} \mathrm{(2,4,} \mathrm{and} 6$ in.) thick (Figs. 2 and 3) indicate this to be the case in that there is no decrease in the toughness levels of the 100- and 150-mm-thick (4- and 6-in.) specimens compared with the 50-mm-thick (2-in.) specimens. Simulations of actual vessels subjected to PTS loadings should be made. The PTS loading may be representative of the loading experienced by the bend specimens being tested as part of the experimental program, and this point needs further study.

4. A detailed reexamination of the thermal shock experiment and pressurized-thermal shock experiment vessel tests previously conducted should be made to study the influence of crack size on these tests from the perspective of shallow-crack enhancement. These tests were conducted at relatively low test temperatures in which the difference in constraint between shallow and deep flaws would be small. However, because these tests may be ones that most closely approach the service loading of concem, this reanalysis is especially important. 
5. Several ORNL investigations of advanced fracture methodologies related to correlation parameters and constraint effects are in progress. These studies were started to obtain an improved understanding of relationships governing the transfer of fracture toughness data from small-scale specimens to large-scale applications and will be valuable in the assessment of safety margins for nuclear vessels with shallow flaws. These investigations consist of several analytical approaches including a maximum principal stress criterion, plastic zone size, and a local stress field approach using K-T or J-Q fracture parameters. Hopefully, these studies will verify the experimental results obtained as part of Recommendation 1 and help to explain theoretically the effect of in-plane constraint on fracture toughness.

6. In the HSST wide-plate tests of A 533 B steel conducted at the National Institute of Standards and Technology (NIST), ${ }^{11}$ crack initiation consistently occurred at $\mathrm{K}_{\mathrm{I}}$ values ranging from two to four times those predicted by the compact-tension (CT) specimens for the A $533 \mathrm{~B}$ specimens. The CT specimens had a/W values of 0.5 , whereas the wide-plate specimens had a/W values close to 0.2 . Thus, although the wide-plate tests were conducted to study arrest behavior, study of the initiation behavior indicates that an a/W ratio can have a significant effect on the behavior of either large specimens or actual vessels as predicted by small-scale laboratory test results of specimens with $\mathrm{a} / \mathrm{W}=0.5$. It is recommended that the wide-plate results from the tests at NIST be reanalyzed using data from the perspective of shallow-flaw testing.

7. In contrast to the test results mentioned in Recommendation 6, the wide-plate results of a $21 / 4 \mathrm{Cr}-1$ Mo steel ${ }^{12}$ with crack depths such that the a/W ratio was $\sim 0.2$ apparently exhibited little effect of crack-depth compared with deep-flaw results. Preliminary assessment indicates that ongoing ORNL studies of advanced fracture methodologies (Recommendation 5) can explain this difference on the basis of a K-T fracture analysis. This difference between the wideplate test results of A $533 \mathrm{~B}$ and $21 / 4 \mathrm{Cr}-1$ Mo stcels should be investigated in detail.

8. The applicability of the Irwin $\beta_{\mathrm{c}}$ or $\beta_{\mathrm{Ic}}$ correction to clastic-plastic shallow-flaw CTOD test results needs to be studied. The $\beta$ correction originally was developed to correct for loss of out-of-plane constraint because of inadequate thickness of very high strength materials with relatively low toughness levels. In the present study, the preliminary results of Figs. 2 and 3 suggest that there is not a significant loss of out-of-plane constraint between $B=50 \mathrm{~mm}(2 \mathrm{in}$.) and $B=100$ or $150 \mathrm{~mm}$ ( 4 or 6 in.) even though the 50- and 100-mm-deep (2- and 4-in.) crack specimens do not meet the validity requirements of E399. How'ever, a distinct difference exists in toughness values for shallow-flaw specimens compared with deep-flaw spe simens because of differences in the in-plane constraint. 
It may be possible to use the $\beta_{\mathrm{Ic}}$ correction factor in reverse; that is, the $\beta_{\mathrm{Ic}}$ factor can be used to predict the behavior of shallow-flaw specimens starting with the existing deep-flaw $\mathrm{K}_{\mathrm{Ic}}$ reference curve as a base. Merkle ${ }^{13}$ use $\mathrm{J}$ the $\beta$ correction to account for the effects of partial transverse restraint on the fracture behavior of vessels with shallow-nozzle corner cracks. This methodology has been used successfully by $\mathrm{ORNL}^{3}$ to predict the effects of crack length on the fracture of the A 533 B beams to date

The significance $\mathrm{c}$ f the $\beta_{\mathrm{Ic}}$ factor as related to in-plane constraint needs to be established inasmuch as its original use was to correct for loss of out-of-plane constraint. However, the results presented in Figs. 2 and 3 show that 50-mm-thick (2-in.) specimens exhibit the same toughness as 150 -mm-thick (6-in.) specimens regardless of crack depth. This behavior would

not be expected using a $\beta_{\mathrm{Ic}}$ correction, and thus the applicability of the $\beta_{\mathrm{Ic}}$ factor for shallow flaws (if not deep flaws alsn) should be re-examined.

9. The significance of the correction procedure developed by Dodds and Anderson ${ }^{14}$ to account for loss of in-plane constraint in structural applications such as RPVs should be established. The key factor is to establish the conditions of constraint in actual vessels with shallow flaws. Their procedure can be very helpful in analyzing the geometry dependence of fracture toughness values for different a/W ratios. Analytical studies of full-thickness vessels under conditions of plane strain (Recommendation 3) should be helpful in this respect.

\section{SUMMARY AND DISCUSSION}

The previous investigations need to be conducted to ensure that the increase in fracture toughness observed in laboratory specimens can be explained theoretically so that the enhanced fracture toughness data can be used to predict the bchavisr of actual RPVs with confidence. This question of transferability of data must he answered before any advantage can be taken in design or analyses of shallow-flaw test results. It is anticipated that the above investigations will verify that the predicted initiation fracture toughness of actual RPVs with shallow cracks is greater than the predicted toughness based on test results of specimens with deep flaws. Even if the increase is small, the improved understanding of the bchavior of shallow flaws in vessels subjected to PTS should be well worth the effort. Hopefully, the preliminary experimental results shown in Figs. 2 and 3 will be substantiated, and the transferability will be established on the basis of the analytical studies. If so, that would lead to the conclusion that the reliability of RPVs is greater than is currently predicted on the basis of deep-crack test results. 
One way of using the enhanced shallow-flaw toughness results would be to develop a new $\mathrm{K}_{\mathrm{c}}$ reference curve for shallow-flaw results. As an example only, "shallow-flaw" reference curve for the A 36 steel tested at the University of Kansas is presented in Fig. 8. These data were developed using CTOD specimens although the results also were analyzed in terms of $\mathrm{J}$. Because relationships exist between $\mathrm{K}, \mathrm{J}$, and CTOD, it is possible to use $\mathrm{K}_{\mathrm{J}}$ or $\mathrm{K}_{\mathrm{CTOD}}$ results to obtain a new shallow-flaw reference curve. Once again, if the various investigations recommended in this report verify that shallow-flaw toughness results can be used safely to predict the behavior of RPVs, a new reference curve such as the example one shown in Fig. 8 could be developed. A new reference curve would be one way to use the enhanced toughness results; another way would be to modify the crack driving force equations by the addition of such parameters as $\mathrm{T}$ or $\mathrm{Q}$ (Recommendation 5).

The issue of whether the actual crack depth, a, or the relative crack depth, $a$ / $W$, is the controlling fracture toughness parameter should be studied as a part of this program. Hopefully, the fact that moderateiy large specimen sizes are tested will make the issue one of secondary imıportance.

ORNL-DWG 91-3193 ETD

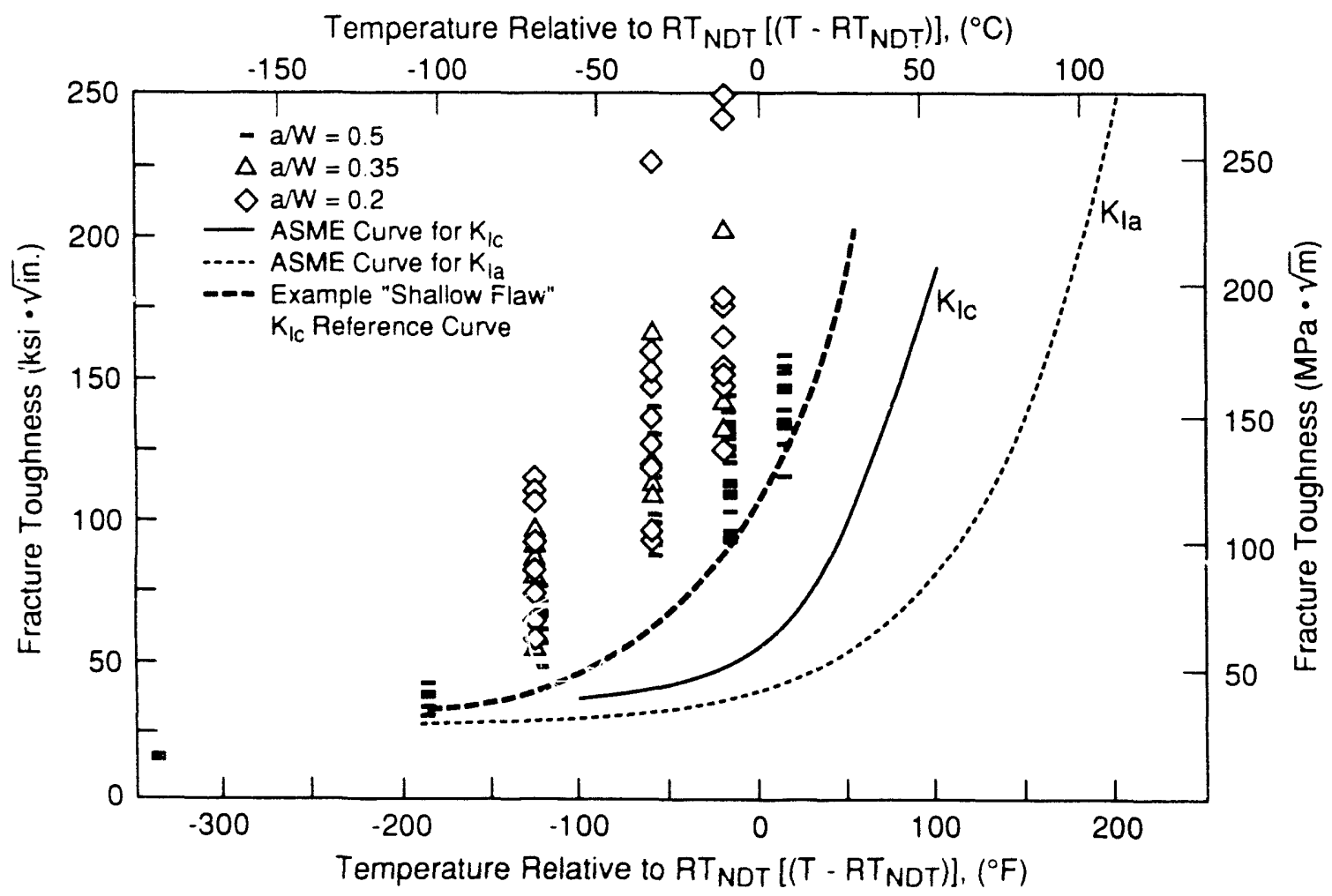

Fig. 8. Comparison of A 36 test results with ASME Sect. XI reference curve as example of "shallow flaw" reference curve. 
Preliminary analysis indicates that three primary factors affect shallow-flaw behavior in either laboratory specimens or actual structures:

1. toughness level-whether measured by K, J, or CTOD,

2. strength level-either yield or flow stress, and

3. crack length, a.

These three parameters appear to be the primary ones based on the fact that $\mathrm{K}, \sigma$, and a, are the primary factors in basic fracture studies of infinite plates. Secondary factors believed to affect shallow-flaw behavior include the inherent size of the specimens and/or structure, again consistent with basic studies of the driving force $\mathrm{K}_{\mathrm{I}}$ in finite-width plates. Thus, the a/W ratio would appear to be of less significance than the absolute crack lengh, a.

In addition to the PTS problem in nuclear RPVs, the preliminary observations in Figs. 1-3 of enhanced shallow-flaw toughness have considerable implications for the application of laboratory test results to failure analyses and specification development in other areas, such as support structures. For failure and fitness-for-purpose analyses, the crack depth selected for laboratory testing should reflect the flaw size and crack-tip constraint present in a given structure. Accurate representation of actual structura' conditions should improve the confidence and reliability of using laboratory specimen test results to predict structural behavior; that is, the automatic adoption of lower-bound toughness values obtained using deep-crack specimens may be unduly conservative. Finally, fracture control plans should establish the required toughness levels of materials using the most probable flaw sizes that can occur in actual structures, for example, support structures as well as RPVs. These flaws certainly should be small compared with most structural dimensions and should thus be considered shallow.

In summary, the enhancement in fracture toughness of an A $533 \mathrm{~B}$ steel, representative of steel used in RPVs, appears to be real. Additional studies, both experimental and analytical, are desirable to provide a sound engineering basis for transferring this information to the structural margin assessment of RPVs with flaws. 


\section{REFERENCES}

1. W. A. Sorem, R. H. Dodds, Jr., and S. T. Rolfe, The University of Kansas, "An Analytical Comparison of Short-Crack and Deep-Crack CTOD Fracture Specimens of an A 36 Steel," WRC Bulletin 351, Welding Research Council, February 1990.*

2. J. A. Smith, Butler Manufacturing Co., and S. T. Rolfe, University of Kansas, "The Effect of Crack Depth to Width Ratio on the Elastic-Plastic Fracture Toughness of a High-Strength Low-Strain Hardening Steel," WRC Bulletin 358, Welding Research Council, November 1990.*

3. T. J. Theiss and G. C. Robinson, Martin Marietta Encrgy Systems, Inc., Oak Ridge Natl. Lab., and S. T. Rolfe, The University of Kansas, "Preliminary Test Results from the HSST Shallow-Crack Fracture Toughness Program," presented in Proceedings of the ASME-PVP Conference, PVP-Vol. 213, pp. 125-130, San Diego, Calif., June 23-27, 1991.

4. T. J. Theiss, Martin Marietta Energy Systems, Inc., Oak Ridge Natl. Lab., "Recommendations for the Shallow-Crack Fracture Toughness Testing Task Within the HSST Program," USNRC Report NUREG/CR-5554 (ORNL/TM-11509), August 1990.†

5. R. D. Cheverton and D. G. Ball, Martin Marietta Energy Systems, Inc., Oak Ridge Natl. Lab., "Pressurized-Thermal-Shock Evaluation of the H. B. Robinson Nuclear Power Plant," USNRC Report NUREG/CR-4183 (ORNL/TM-9567/N1), September 1985.†

6. R. D. Cheverton and D. G. Ball, Martin Marietta Energy Systems, Inc., Oak Ridge Natl. Lab., "Pressurized-Thermal-Shock Evaluation of the Calvert Cliffs Nuclear Power Plant," USNRC Report NUREG/CR-4022 (ORNL/TM-9408), September 1985.†

7. R. D. Cheverton and D. G. Ball, Martin Marietta Energy Systems, Inc., Oak Ridge Natl. Lab., "Preliminary Development of an Integrated Approach to the Evaluation of Pressurized Thermal Shock as Applied to the Oconee 1 Nuclear Power Plant," USNRC Report NUREG/CR-3770 (ORNL/TM-9176), May 1986.†

8. 1989 ASME Boiler and Pressure Vessel Code, Section XI, "Rules for Inservice Inspection of Nuclear Power Plant Components." 
9. T. V. Marston, "Flaw Evaluation Procedures-Background and Applications of ASME Section XI," Appendix A-NP-719-SR, Special Report, August 1978, ASME-Section XI Task Group on Flaw Evaluation. ${ }^{\dagger}$

10. J. G. Merkle, Martin Marietta Energy Systems, Inc., Oak Ridge Nat. Lab. "An Examination of the Size Effects and Data Scatter Observed in Small-Specimen Cleavage Fracture Toughness Testing," USNRC Report NUREG/CR-3672 (ORNL/TM-9088), April 1984. ${ }^{\dagger}$

11. D. J. Naus et al., Martin Marietta Energy Systems, Inc., Oak Ridge Natl. Lab., "CrackArrest Behavior in SEN Wide Plates of Quenched and Tempered A 533 Grade B Stecl Tested Under Nonisothermal Conditions," USNRC Report NUREG/CR-4930 (ORNL/6388), August 1987. ${ }^{\dagger}$

12. D. J. Naus et al., Martin Marietta Energy Systems, Inc., Oak Ridge Natl. Lab., "CrackArrest Bchavior in SEN Wide Plates of Low-Upper-Shelf Base Metal Tested Under Nonisothermal Conditions," USNRC Report NUREG/CR-5451 (ORNL/RF-6584), August $1990 . \dagger$

13. J. G. Merkle, "An Approximate Method of Elastic-Plastic Fracture Analysis for Nozzle Comer Cracks," Elastic.Plastic Fracture, ASTM STP 668, 674-702 (1979).*

14. R. H. Dodds, T. L. Anderson, and M. T. Kirk, "A Framework to Correlate a/W Ratio Effects on Elastic-Plastic Fracture Toughness $\left(\mathrm{J}_{\mathrm{c}}\right)$," Int. J. Fract. 48, 1-22 (1991).*

*Available in public technical libraries.

Available from National Technical Information Service, Springfield, VA 22161.

$\ddagger$ Available from American National Standards Institute, 1430 Broadway, New York, NY 10018, Copyrighted. 
NUREG/CR-5767

ORNL/Sub/90-SH640/1

Dist. Category RF

Internal Distribution

1. D. J. Alexander

2. B. R. Bass

3. J. W. Bryson

4. S. H. Buechler

5-6. R. D. Cheverton

7. J. M. Corum

8. W. R. Corwin

9. T. L. Dickson

10. F. M. Haggag

11. J. J. Henry

12. W. F. Jackson

13. J. E. Jones Jr.

14. S. K. Iskander

15. J. Keeney-Walker

16. W. J. McAfee

17. D. E. McCabe
18. J. G. Merkle

19. R. K. Nanstad

20. D. J. Naus

21-26. W. E. Pennell

27. C. B. Oland

28. C. E. Pugh

29. G. C. Robinson

30. D. K. M. Shum

31. R. L. Swain

32-35. T. J. Theiss

36. ORNL Patent Section

37. Central Research Library

38. Document Reference Section

39-40. Laboratory Records Department

41. Laboratory Records (RC)

\section{External Distribution}

42. L. C. Shao, Director, Division of Engineering, U.S. Nuclear Regulatory Commission, Washington, DC 20555

43. C. Z. Serpan, Jr., Division of Engineering, U.S. Nuclear Regulatory Commission, Washington, DC 20555

44-45. M. E. Mayfield, Division of Engineering, U.S. Nuclear Regulatory Commission, Washington, DC 20555

46. A. Taboada, Division of Engineering, U.S. Nuclear Regulatory Commission, Washington, DC 20555

47. W. L. Fourney, Department of Mechanical Engineering, University of Maryland, College Park, MD 20742.

48. J. D. Landes, The University of Tennessee, Knoxville, TN 37996-2030

49-55. S. T. Rolfe, The University of Kansas, Lawrence, KS 66045-2235

56. A. R. Rosenfield, Battelle Columbus Division, Columbus, OH 43201

57. C. W. Schwartz, Department of Civil Engineering, University of Maryland, College Park, MD 20742

58. E. T. Wessel, 312 Wolverine, Haines City, FL 33844

59. Office of Assistant Manager for Energy Research and Development, DOE-OR, Oak Ridge, TN 37831

60-61. Office of Scientific and Technical Information, P. O. Box 62, Oak Ridge, TN 37831

62-306. Given distribution as shown in category RF (NTIS-10) 

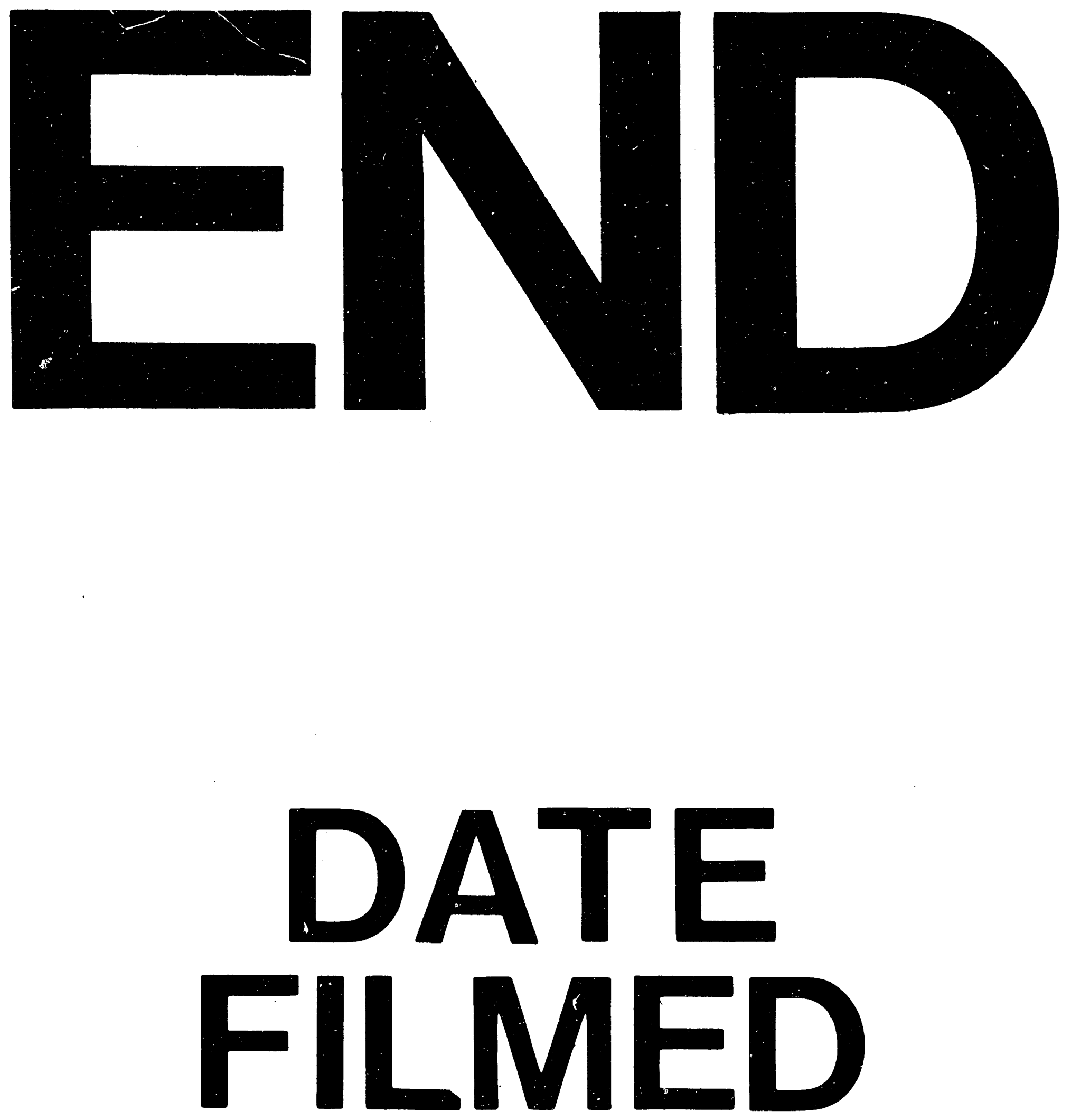

$t$

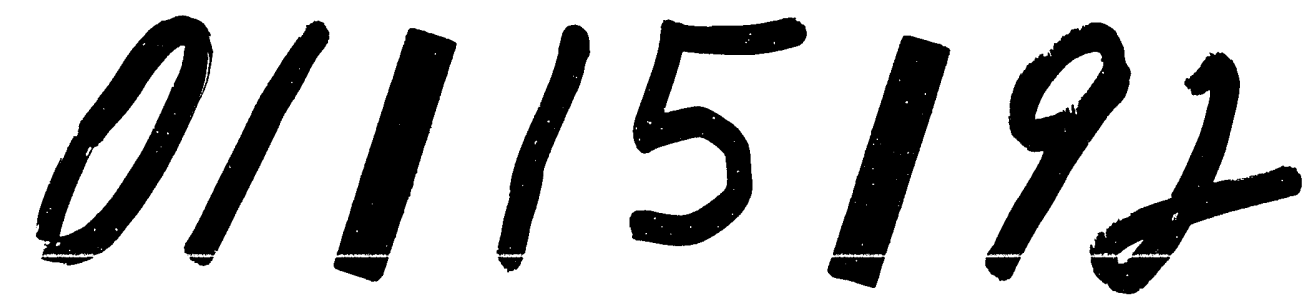




$$
\text { - }
$$

